\title{
Beneficial autoimmunity at body surfaces - immune surveillance and rapid type 2 immunity regulate tissue homeostasis and cancer
}

\section{Tim Dalessandri and Jessica Strid *}

Division of Immunology and Inflammation, Department of Medicine, Imperial College London, London, UK

\section{Edited by:}

Fang-Ping Huang, Imperial College

London, UK

\section{Reviewed by:}

Masaaki Murakami, Hokkaido University, Japan

Yasmina Laouar, University of

Michigan, USA

\section{*Correspondence}

Jessica Strid, Division of Immunology and Inflammation, Department of

Medicine, Imperial College London,

London W12 ONN, UK

e-mail:j.strid@imperial.ac.uk

\begin{abstract}
Epithelial cells (ECs) line body surface tissues and provide a physicochemical barrier to the external environment. Frequent microbial and non-microbial challenges such as those imposed by mechanical disruption, injury or exposure to noxious environmental substances including chemicals, carcinogens, ultraviolet-irradiation, or toxins cause activation of ECs with release of cytokines and chemokines as well as alterations in the expression of cell-surface ligands. Such display of epithelial stress is rapidly sensed by tissue-resident immunocytes, which can directly interact with self-moieties on ECs and initiate both local and systemic immune responses. ECs are thus key drivers of immune surveillance at body surface tissues. However, ECs have a propensity to drive type 2 immunity (rather than type 1) upon non-invasive challenge or stress - a type of immunity whose regulation and function still remain enigmatic. Here, we review the induction and possible role of type 2 immunity in epithelial tissues and propose that rapid immune surveillance and type 2 immunity are key regulators of tissue homeostasis and carcinogenesis.
\end{abstract}

Keywords: immune surveillance, Type 2 immunity, epithelial cells, tissue homeostasis, carcinogenesis, IgE, intraepithelial lymphocytes, sterile stress

Epithelial cells (ECs) are the main constituent of tissues lining body surfaces like the skin, intestine, lungs, and genitourinary tract. They regulate crucial life processes such as micronutrient absorption, gaseous exchange, and thermo- and hydro-control whilst also providing a physiochemical barrier to the external environment against microbes and a plethora of non-microbial stressors. ECs are extremely dynamic and versatile cells and it is becoming increasingly clear that they are also intimately involved in the induction and regulation of local tissue- and systemic immune responses. Disruption of epithelial surfaces may therefore result in dysregulated body processes and penetrance to deeper tissues by microbes or noxious moieties. In addition, the direct response of ECs to tissue disruption strongly affects resident immunocytes and their subsequent regulation of both local and systemic innate and adaptive immunity. A growing body of evidence both from mouse models and human genetics suggest that EC dysregulation can be a primary cause of pathology in different tissues. Given the multifaceted biological actions of ECs and the multitude of challenges imposed on epithelial tissues, it is reasonable to think that ECs in conjunction with tissueresident immunocytes possess mechanisms, both immunological and non-immunological, to maintain healthy barrier homeostasis and to minimize inflammation and cellular dysregulation. Indeed, ECs are now known to be highly immunomodulatory by virtue of the cytokines, chemokines, damage-associated molecular pattern (DAMP) molecules, and major histocompatibility (MHC) gene products they express; a repertoire that has collectively been termed the "epimmunome" (1). ECs express pattern-recognition receptors (PRRs) including toll-like receptors (TLRs), NOD-like receptors (NLRs), RIG-I-like receptors (RLRs), and a variety of
"NK" receptor ligands, enabling them to respond to a wide variety of microbial and non-microbial (including self) moieties and disseminate the response to immunocytes. The NLR-inflammasome complex allows ECs to respond to non-microbial sterile stress elicited by toxins, irritants, and (for skin keratinocytes) ultraviolet (UV) light (2); the most pervasive environmental DNA-damaging agent (3). Thus, ECs express a suite of sensors for detecting differing insults and challenges at the body surfaces, and an armory of soluble and cell-surface molecules to direct an appropriate, restorative response. These epithelial-driven responses in health sculpt and modulate tissue homeostasis and local tissue immunity, in a manner that aids morphological tissue homeostasis, restoration of the epithelial barrier following injury, and elimination or expulsion of microbial and non-microbial insults. Here, we review how ECs drive immunity at body surfaces and how this is involved in regulating immune surveillance, tissue immune homeostasis, and cancer.

\section{EPITHELIAL CELLS AND THEIR RESPONSE TO CHALLENGE}

The vast majority of environmental challenges occur at epithelial surfaces. The repertoire of responses available to ECs to combat these daily challenges is immense. For example, EC-derived cytokines include IL-1, IL-6, IL-10, IL-18, IL-25, IL-33, TNF $\alpha$, and thymic stromal lymphopoietin (TSLP). Pro-IL-1 $\alpha$ and pro-IL-1 $\beta$ are constitutively produced by ECs, particularly skin keratinocytes, and are secreted following exposure to noxious stimuli or tissue damage. Corneocytes (non-nucleated skin ECs) release IL-1 $\alpha$ in the skin in response to disruption of the outermost surface, the stratum corneum (4), while UV-irradiation induces IL-1 $\beta$. In addition to agonistic effects on tissue macrophages, IL- $1 \alpha$ induces 
growth-factor expression from tissue fibroblasts, prompting a replicative burst in neighboring ECs to repair damage (5). The pro-inflammatory cytokines IL- 6 and TNF $\alpha$ are produced in large quantities by damaged ECs; the former of which can also be used as a STAT-3-dependant autocrine growth factor, in healthy and cancerous epithelium (6). The most robustly expressed cytokines upon any EC insult however are IL-25, IL-33, and TSLP. In common, these three cytokines can drive type 2 immune responses, which thus impart a particular propensity of epithelial tissues to induce type 2 immunity. Such predisposition of stressed ECs may underlie the high frequency of allergic and atopic disease at the skin and mucosal surfaces. However, despite the intense interest in this area, the cellular and molecular linkage of type 2 immunity to barrier- and EC disruption is not clearly understood - nor is the functional role of this type of immunity to EC homeostasis or immune surveillance yet fully elucidated.

IL-25, also know as IL-17E, is a member of the IL-17 cytokine family. Despite bearing some amino acid sequence homology to the best-characterized IL-17 cytokines, IL-17A and IL-17F, IL-25 has divergent biological functions and promotes Th2 rather than Th17 responses in vivo. IL-25 directly amplifies expression of the Th-2 mediators IL-4, IL-5, and IL-13, and supports production of Th2 serum immunoglobulins (7). IL-25 was first reported with high steady-state mRNA expression in the kidney, and moderate to low expression in other organs and the peripheral tissue (8). Subsequently, it was found by multiple groups to be important in type 2-mediated immunity to enteric parasites, such as Trichuris muris (9), and is upregulated in the gut upon EC-sensing of commensal bacteria (10). The mouse gut parasite Heligmosomoides polygyrus bakeri elicits the EC-derived cytokine, IL-1 $\beta$, which suppresses IL-25 and IL-33 and promotes pathogen chronicity by attenuating expulsive type 2 responses (11), suggesting that IL-25 is particularly important in maintaining immunity to gut pathogens. Similarly, mice and humans subjected to parenteral nutrition have impaired mucosal immunity, due to reduced gut luminal levels of antimicrobial effectors, but administration of exogenous IL-25 to parenteral nutrition-fed mice was found to be protective against enteric bacterial invasion (12). In allergic models, IL-25 expression is upregulated upon exposure to allergens both in murine or human lung EC lines and in primary murine lung ECs (13). Elevated protein levels have also been found in tissues of patients with allergic disease in the lung and skin (14). IL-25 has been found to drive tissue (airway) remodeling, and expression of the other major EC cytokines IL-33 and TSLP in a house dust mite model of allergy (15), and drive pulmonary fibrosis by inducing IL-13 expression from lung innate lymphoid cells (ILCs) in mice challenged with lung Schistosoma mansoni eggs (16). In addition to production by ECs, dermal dendritic cells (DCs) have been reported to be a major source of IL-25 in atopic dermatitis (AD) patients (17), while IL-25 and IL-33-activated ILC2s in mouse skin promote AD-like inflammation (18). These reports and others highlight an interesting crosstalk and autocrine regulation of EC-derived effectors, as well as a role for IL-25 in augmenting epithelial barrier immunity, or conversely promoting pathological Th2 tissue inflammation, in differing settings.

IL-33 is a multi-functional protein. The full length protein is localized in the nucleus but following cleavage the c-terminal fragment acts as a cytokine which binds the receptor ST2. IL33 was recently discovered as an IL-1 family member with type 2-promoting functions similar to IL-25. It is expressed by ECs, macrophages, DCs, and mast cells in vivo and its cytokine function drives IL-4, IL-5, and IL-13 expression and differentiation of Th2 CD4 ${ }^{+}$T cells (19). IL-33-induced IL-4 production appears to be mainly from innate cells and together these two cytokines will induce proliferation of B cells and amplify IgE synthesis (20). Similar to IL-25, IL-33 acts in an autocrine fashion to promote TSLP expression by ECs, particularly in response to gut nematodes, where IL-33 mRNA can be detected rapidly following colonization (21). Interestingly, the efficacy of IL-33 in this infection model (and others) seems to be highly time-dependent, with administration of exogenous IL-33 at late time points post-infection being ineffective in promoting type 2 responses that would otherwise resolve infection. IL-33 is highly expressed by intestinal ECs and inflammatory infiltrates in ulcerative colitis, with IL-33 cleavage products being detected in the serum (22). IL-33 is also rapidly released and detectable in bronchoalveolar lavage fluid following lung allergen exposure in humans, suggesting it is a rapid type 2 mediator in sites additional to the gut (23). Protective as well as immunopathological roles of EC-derived IL-33 have been described in the skin. Transgenic over-expression of IL-33 in mouse skin, driven by a keratinocyte-specific promoter, induces a spontaneous dermatitislike disease and activates ILC2s in the dermis (24). It has also been shown in a phorbol 12-myristate 13-acetate model of skin inflammation that mice deficient for the IL-33 receptor, ST2, do not exhibit IL-33-dependant skin inflammation (25). Similarly in human inflammatory conditions, IL-33 has been reported to be upregulated in clinical psoriatic lesions and the serum of skin sclerosis patients (26). Conversely, mice treated with exogenous IL-33, following full-thickness skin wounding, demonstrate dramatically improved wound-healing, collagen deposition, and expression of extracellular matrix proteins indicative of tissue repair (27). These reports suggest a particularly rapid and acute role for IL-33 in cutaneous homeostasis and gut integrity whereas constitutive, late, or dysregulated expression may be involved in a variety of chronic inflammatory conditions. This temporally coordinated aspect fits well with current thinking of IL-33 as an "alarmin," whereby its immediate release from intranuclear stores by damaged, apoptotic, or necrotic cells rather than a classic Golgi-mediated secretion pathway (19) facilitates a rapid and restorative response to tissue damage.

TSLP is produced almost exclusively by ECs of the lung, tonsils, intestine, and skin (13), and is upregulated in response to tissue damage (28), various TLR ligands and infection, or exposure to type 2 cytokines such as IL-4, IL-13, IL25, and IL-33 (29). A protective role of TSLP in intestinal immunity to T. muris has been well described; mice which are knockouts for IKK $\beta$ fail to produce TSLP in response to infection, and subsequently develop chronic intestinal inflammation (30). Mechanistically, EC-derived TSLP suppresses p40 and upregulates OX40L expression in DCs, a costimulatory molecule with a propensity to license Th2 responses in $\mathrm{CD}^{+}{ }^{+} \mathrm{T}$ cells (31). TSLP also augments Th2 cytokine production by direct effects on $\mathrm{CD} 4^{+} \mathrm{T}$ cells and has indirect, agonist effects on a variety of granulocyte populations including mast cells and basophils. Similar to IL-25 and IL-33, inappropriate 
expression or dysregulation of TSLP is implicated in a number of inflammatory diseases including the triad of atopic diseases; asthma, allergic rhinitis, and AD (31). TSLP is required for allergic lung inflammation in mice exposed to inhaled antigen, and TSLP receptor knockout animals do not develop lung inflammation in this model. Interestingly, these animals do develop strong Th1 responses with high IFN $\gamma$, IL-12, and IgG2a (32), highlighting how a single epithelial-derived molecule can skew adaptive immune responses in response to tissue-challenge. In humans, AD sufferers show high TSLP expression in lesional skin (33), and mice with induced expression of TSLP in the epidermis develop spontaneous AD-like pathology (34). Production of TSLP is however critically important for resistance to skin carcinogenesis in mouse models $(35,36)$.

Further to cytokines and chemokines, ECs can release other proteins upon cellular stress. Of note, they can produce hedgehog morphogens, which are a family of secreted proteins that regulate a wide variety of physiological processes including tissue development during embryogenesis and tissue homeostasis as well as being implicated in carcinogenesis (37). Sonic Hedgehog h ( $\mathrm{Hh})$ expression was recently found to be upregulated in lung ECs in models of allergic disease, and lung resident $\mathrm{T}$ cells were shown to respond locally to EC-derived Hh by upregulating IL-4 (38). This demonstrates that ECs also produce non-classical immune modulators, such as tissue morphogens, which appear to contribute to the robust induction of type 2 immunity in epithelial tissues.

In addition to the secreted and soluble molecules produced by ECs, they also express a variety of cell-surface molecules enabling them to directly interact with resident and infiltrating immunocytes. For example, ECs express E-cadherin that engage CD103, which is constitutively expressed on intraepithelial lymphocytes (IELs) and tissue DCs such as the epidermal Langerhans cells (LCs). ECs also express $\mathrm{T}$ cell costimulatory ligands, although it remains unclear as to what extent ECs express the classical B7.1 and 2 molecules, they clearly express PD-L1 and PD-L2 (39). Some members of a novel family of B7-related molecules, the butyrophilins, appear to be preferentially expressed on ECs and have been implicated in EC-immune regulation (40) as have Skint family members which are exclusively expressed on ECs and have profound impact on IEL development and function $(41,42)$. Thus via appropriate receptor-ligand interactions ECs are capable of initiating and sculpting both local tissue immunity and further downstream systemic immunity. Under conditions of physiochemical tissue disruption or barrier perturbation (1), infection (43), genotoxic stress (44), sterile inflammation, or heavy proliferation (45), ECs respond by upregulating additional self-encoded and cell-surface markers, which are often termed as "stress antigens" as they are indicative of a dysregulated state of the epithelium. The EC stress antigens have an important role in initiating and directing tissue immune responses during perturbations and as such these will be discussed in more detail in the Section "Immune Surveillance" below.

\section{EPITHELIAL CELLS AND THEIR NEIGHBORS}

In close association with ECs, the epithelial tissues are home to several specialized subsets of immunocytes. IELs are found in all epithelial tissues, but have most notably been studied in the intestine and skin. IELs are adaptive T cells carrying RAGdependent rearranged $\mathrm{T}$ cell receptors (TCRs), nevertheless they are often MHC non-restricted cells and express many innate receptors allowing them to react to stress antigen with "innate-like" response kinetics. The IELs are a mixture of $\alpha \beta$ and $\gamma \delta$ T cells, which are either $\mathrm{CD} 4^{-} \mathrm{CD} 8^{-}$or coexpress a CD8 $\alpha \alpha$ coreceptor. The ratio of $\alpha \beta$ to $\gamma \delta$ T cells depends on the anatomical site as well as the species. IEL compartments are often much less diverse than systemic $\mathrm{T}$ cells (for example in the mouse skin and uterus they are essentially monoclonal), implying that these cells recognize predictable antigens encountered in specific tissues - these antigens could be either pathogen encoded or self-encoded molecules that reflect a dysregulated state of the tissue they inhabit. Not many IEL TCR-specificities have yet been defined, but it seems clear that both their recognition capabilities and mode of activation are distinct from systemic T cells (46). Particularly, it has been proposed that IELs are primarily autoreactive $\mathrm{T}$ cells that have been agonist-selected, recognize tissue stress antigens, and have regulatory properties (47). The murine skin for example contains a specialized subset of $\gamma \delta(\mathrm{TCR})^{+}$IELs called dendritic epidermal T cells (DETC) that exclusively carry a $V \gamma 5 \mathrm{~V} \delta 1 \mathrm{TCR}-$ a TCR arrangement only found on epidermal IELs (and on the progenitor fetal thymic population). The skin epithelia also contain a specialized subset of DCs, the epidermal LCs. Both LC and DETC infiltrate the epithelium very early during stratification of the skin ECs, and are long-lived and likely self-renewing immune compartments, which clearly integrate and physically interact with the ECs.

In addition to the "unconventional" $\mathrm{T}$ cells in the epithelium, more conventional CD $8 \alpha \beta^{+} \alpha \beta$ T cells have been shown to rapidly accumulate in tissues upon infection, where they can become resident memory $\mathrm{T}$ cells and provide protective antigen-specific responses. This was elegantly shown in the skin following local infection with herpes simplex virus (48) or vaccinia virus (49), which induced a rapid influx of antigen-specific $\mathrm{CD}^{+} \alpha \beta \mathrm{T}$ cells both into the epithelial epidermal layer and the underlying dermis. Interestingly, these infiltrating $\mathrm{CD}^{+} \alpha \beta$ T cells were shown to populate the entire skin and provide long-lasting protection against re-infection as a continuing tissue-resident memory $\mathrm{T}$ cell population. In steady state, the subepithelial layer of most tissues contains a diverse set of immunocytes that can all contribute to epithelial-immune surveillance. These include tissue-specific resident populations of myeloid cells, such as DC, macrophages and mast cells, lymphoid cells, such as $\mathrm{CD}^{+}{ }^{+}$or $\mathrm{CD}^{+} \alpha \beta$ T cells, $\gamma \delta \mathrm{T}$ cells, and ILCs, as well as stromal fibroblasts. In fact, it is becoming increasingly apparent that different tissues constitutively harbor a variety of specialized immunocytes in the subepithelial space. For example, in human skin a population of IL-22 and growth factor producing T cells (Th22) can rapidly enter the epithelium upon challenge and be involved in epidermal remodeling (50). Similarly, the gut contains a resident IL-22 producing population of NK-like cells (51). In recent years, an array of different ILCs has been discovered that are resident in the subepithelial tissue layer. Different subsets of ILCs dominate in particular tissues and their specialized functions are starting to be elucidated; many of them contribute to both homeostatic and pathophysiological conditions in the tissue they inhabit (52). The subepithelial immunocytes can respond to 
epithelial cues and be recruited into the epithelium upon damagein addition systemic immune cells can be recruited both to the subepithelial and epithelial layer. In sum, the epithelium and body surface tissues are home to an intricate array of immunocytes, which can interact and integrate activities in numerous complex ways that likely differ substantially depending on the anatomical site and the challenge encountered. Additional research is required to understand the interaction between different resident immunocytes in the tissues and how their responses may be integrated to regulate local and systemic immunity.

\section{TYPE 2 IMMUNITY AND ITS TRIGGERS}

Epithelial cells and EC-associated leukocytes such as IELs can clearly drive local and systemic type 2 immunity (53). More conventionally, however, type 2 immunity is thought to be mediated primarily by Th2 cells, IgE and IgG1 antibodies, as well as a host of innate immune cells such as mast cells, basophils, eosinophils, alternatively activated macrophages, and ILCs. The type 2 immune response in vivo is accordingly extremely heterogeneous and it is surprisingly poorly understood how type 2 immunity is induced, regulated - and indeed what its primary physiological function is. Type 2 immune responses are classically induced by macroparasites and conventional thinking holds that type 2 immunity has evolved to protect against infection by parasites such as helminthes and ticks. However, this is probably a too simple explanation, as it is not true that all parasites are fought by $\operatorname{IgE}$ and type 2 immunity. Although IgE levels are raised in people as well as mice with helminth infections, IgE is dispensable for immunity to many helminthes and much of the IgE raised is not specific to the parasite (54). Type 2 immunity is also notoriously activated in response to a broad range of different environmental challenges and antigens. Such non-infectious stimuli that trigger type 2 immunity are collectively termed allergens and form the basis of a host of allergic disorders like asthma, allergic rhinitis, food allergies, and AD. Type 2 immune responses have been explored largely in the context of helminth infections and allergic diseases. They have been thought to provide a host-beneficial role only as defense against macroparasites, whereas allergic reactions are most commonly explained as a detrimental consequence of a misdirected response mimicking parasite immunity. This paradigm is now changing and with more triggers of type 2 immunity being elucidated (Figure 1) it seems plausible that type 2 immunity can provide host-benefits in settings other than against parasites. In 1991, Profet published an inspired hypothesis suggesting that the physiological role of allergic responses was an immunological defense against toxins (55). This idea is resonating with recent data $(56,57)$ and the hypothesis has been recharged and expanded into a broader model of intentional allergic host defense not only against helminthes but also

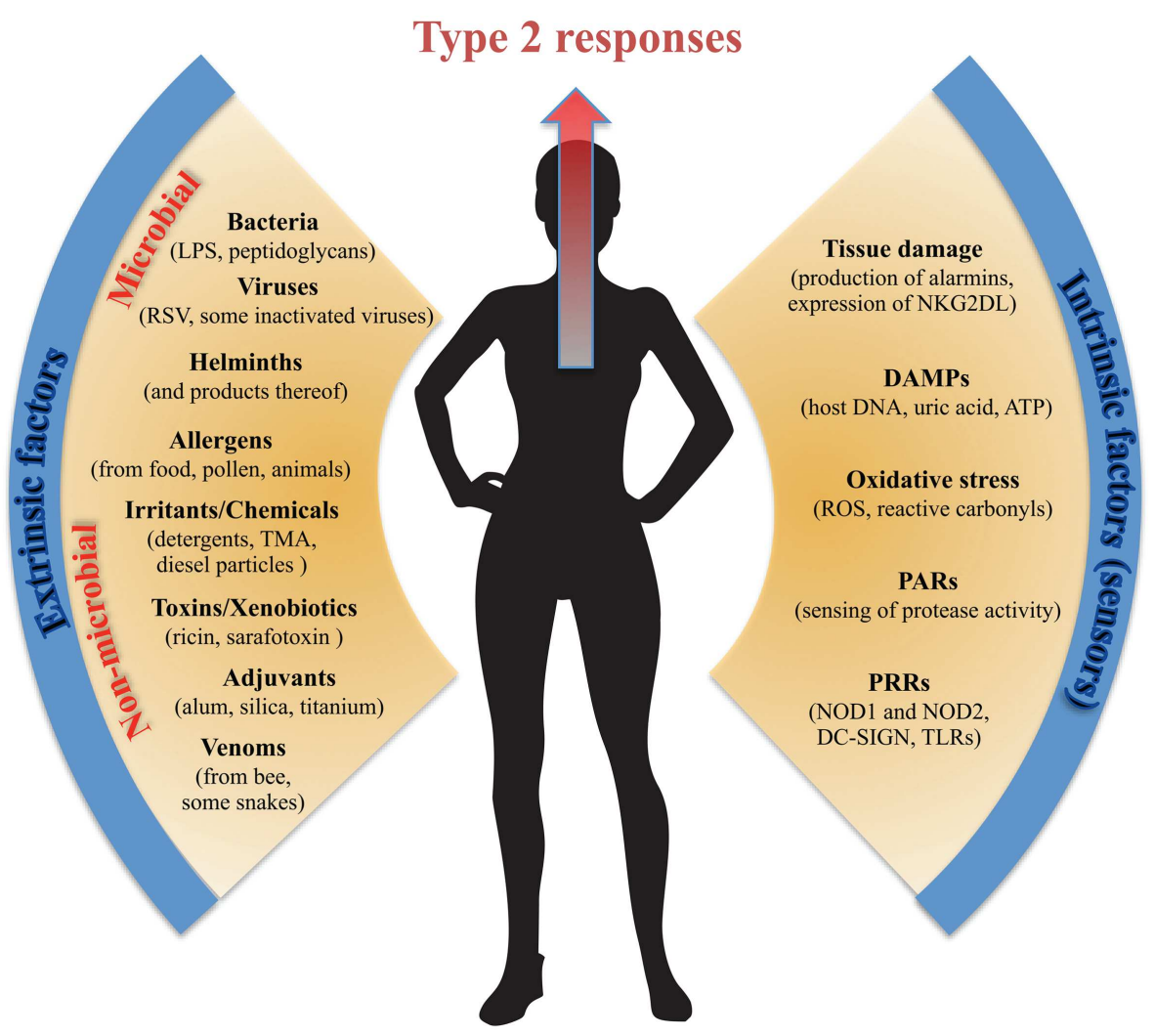

FIGURE 1 | Extrinsic and intrinsic factors promoting type 2 immunity. Type 2 immunity can be triggered by an array of diverse extrinsic stimuli from both infectious and non-infectious sources and is most potently induced at the body surface tissues. Equally, the intrinsic cellular mechanisms inducing and/or sensing type 2-triggering extrinsic stimuli are many and diverse. In common, most of the extrinsic factors promoting type 2 immunity, as well as the intrinsic factors sensing them, are founded on a breach of the protective barrier of the body and thus on tissue and cellular damage. 
non-infectious environmental factors such as venoms, chemical irritants, and xenobiotics (58). Accordingly, there may be multiple pathways that lead to type 2 immunity and $\operatorname{IgE}$ - some more classically "adaptive" and some more "innate" (59). The route to type 2 immunity and whether protection or allergic sensitization is the outcome may depend on tissue context, allergen, dose, genetics, and species. Common for all type 2 immune responses is that their effector functions converge at the epithelial surfaces (skin and mucosa), vasculature, and smooth muscles where they promote barrier defenses and expulsion. Conspicuously, allergic disorders, unlike other immune pathologies, exclusively affect epithelial tissues that interface with the environment.

Type 2 immunity can be triggered by a bewildering array of molecules from both infectious and non-infectious sources (Figure 1). Much work has been done to try and identify a unifying framework for what makes a substance "an allergen" (60), but common allergens such as peanut, shellfish, pollen, nickel, bee venom, latex, house dust mite, and penicillin appear to have little in common in terms of their chemical structure or origin. In addition, type 2 immunity can be triggered by certain vaccine adjuvants [alum most notably $(61)$ ], noxious toxins $(56,58)$, environmental irritants and chemicals $(62,63)$, as well as certain infections or bacterial products (64). One commonality between both infectious and non-infectious triggers of type 2 immunity that may have been less well appreciated is that many are insults inducing some level of physical trauma that breaches the protective barrier of the body. Tissue damage, at least in the absence of strong type 1-promoting pathogen-associated molecular pattern (PAMP) signaling, appears to be a potent mechanism driving type 2 immunity. Tissue damage induces rapid release of several epithelium-derived cytokine alarmins, such as IL-33, TSLP, and IL-25 (reviewed above) - all of which can drive downstream type 2 immunity. In a macroparasite infection, the large size of the parasite and the consequent tissue damage it causes during invasion may be the most important factor in inducing type 2 immunity (65), although some parasite-derived products with direct type 2 polarizing capacity may also exist (66). The tissue-damage caused by macroparasites may be modeled by ingestion of large inert particle structures. Interestingly, it has been shown that inert silica and titanium particles induce innate type 2 immunity and can be used as adjuvants promoting Th2 responses by pathways independent of TLR4 and MyD88 $(67,68)$. These particles may induce cellular damage and consequently activate endogenous danger- or stresssignals. That "injury" or cellular stress alone can support induction of type 2 immunity is strongly supported by results showing that transgenic up-regulation of the NKG2D stress-ligand Rae-1 on ECs promote potent type 2 immunity and IgE to innocuous antigens (53). This rapid innate-like IgE response is also independent of MyD88 (53). Cellular damage may also explain the type 2inducing effect of the adjuvant alum as injection of alum causes the release of DAMPs, like uric acid and host cell DNA $(61,69)$. Uric acid has been shown to drive type 2 immunity and again this is via pathways independent of both MyD88 and the inflammasome (69). Host DNA signaling intriguingly appears to differentially regulate IgG1 and IgE production following alum-adjuvanted immunization, where host DNA induces primary B cell responses with IgG1 through interferon response factor 3 (Irf3)-independent mechanism but more canonical Th2 responses and IgE through an Irf3-dependent mechanism (70). Furthermore, extracellular ATP, presumably released from damaged cells, binds to $\mathrm{P} 2$ purinergic receptors and triggers IL-33 release and innate type 2 immune responses in the lung (71). Oxidative stress, which is widespread and entwined with pathological processes, has also been shown to be involved in orchestrating type 2 immunity. For example, induction of reactive oxygen species (ROS) in ECs induces oxidation of lipids that in turn triggers TSLP release by ECs (72) and oxidative stress has been shown to induce reactive carbonyl adduction, which is reported to be a potent driver of type 2 immunity (73). DAMPs thus appear to be part of both the initiation and amplification of type 2 immunity and may as such also play an important role in allergic diseases.

Another feature that contributes to the induction of type 2 immunity by some allergens is their serine or cysteine protease activity. Allergens such as Der P1 (from house dust mite) and papain (from papaya fruit) appear to rely on their protolytic function as inactive forms of these proteins do not induce type 2 immunity (60). A cysteine protease from the parasite Leishmania Mexicana has also been shown to induce type 2 immunity and this could be blocked by protease inhibitors (66). The importance of controlling enzymatic activity at epithelial surfaces is dramatically demonstrated in patients with Netherton syndrome. Netherton syndrome, which is caused by hereditary mutations in the serine protease inhibitor, LEKTI, presents with severe disruption in barrier function and persistent atopy, allergic disease, and $\mathrm{AD}$ (74, 75). The mutation in LEKTI results in persistent activation of protease-activated receptor (PAR)-2 and induction of TSLP and type 2 immunity (76).

Other endogenous stress-signals, for example the NLR receptors, NOD-1, and NOD-2, can polarize antigen-specific immune responses toward Th2 and thus contribute to the onset of adaptive immunity $(77,78)$. Interestingly, NOD-1 and NOD-2 expression within the stromal compartment is necessary to prime effector $\mathrm{CD}^{+}{ }^{+} \mathrm{Th} 2$ responses and full Th2 induction is dependent on stromal TSLP (79). The type 2 -inducing innate immune sensing is in these cases recognition of bacterial-derived products (peptidoglycans) and not self- or environmental antigens. Although the role of PAMPs and PRRs such as TLRs are usually associated with type 1 immunity, there are other examples in which TLR stimuli can induce type 2 responses. For example, low doses of lipopolysaccharides (LPS) have been proposed to promote Th2 cell responses (whereas high doses promote Th1) (80) for which stromal expression of TLR4 is critical (81). Certain microbial stimuli that signal via DC-SIGN induce Th2 biased responses and many TLR2 agonists have also been shown to suppress Th1 and promote Th2 responses (82). Furthermore, in the case of allergens, there is evidence that some can be directly sensed by PRRs; house dust mite allergens (83) as well as nickel (84) can signal via TLR4 for instance.

Given the vast array of molecules that can trigger type $2 \mathrm{immu}$ nity and the many innate and adaptive immune cells involved in orchestrating the response it seems reasonable that there are several routes to inducing type 2 responses and that these may yield a qualitatively different kind of type 2 immunity. The conventional mode of inducing type 2 immunity and high affinity antigenspecific IgG1 and IgE antibody has since long been described and 
substantiated. Activated $\mathrm{CD} 4^{+} \alpha \beta$ Th cells upregulate CD40L and secrete IL-4 and IL-13, whereby they promote germ-line transcription of the $\gamma 1$ and $\varepsilon$ heavy chain to initialize class switching. This requires cognate interactions between B cell MHC II molecules and the TCR-CD3 complex. However, perhaps especially with regards to IgE, there appears to be additional non-conventional modes of inducing class switching and the requirement for $\mathrm{T}$ cell help may differ. In contrast to orthodox belief, mice that are deficient in $\alpha \beta \mathrm{T}$ cells have highly elevated levels of IgE antibodies and class switch particularly efficient to $\operatorname{IgG1}$ and $\operatorname{IgE}(85,86)$. Mice lacking the linker for activation of T cells (LAT) adapter protein (87) or the Tec kinase ltk also have elevated levels of $\operatorname{IgE}(88,89)$, which may be regulated non-conventionally by $\gamma \delta$ T cells. Evidence for a non-conventional route to IgE has also been demonstrated during the $\gamma \delta \mathrm{T}$ cell dependent "lymphoid stresssurveillance response" in the context of stressed skin epithelium (53). It has been established that the IgE produced in immunodeficient mice differ from conventional adaptive IgE not only by being MHC II-mediated T cell cognate independent but also by lacking dependence on germinal centers and thus producing $\operatorname{IgE}$ without significant somatic hypermutations (90). Moreover, this "natural" IgE also appears to be mainly self-reactive $(85,90)$. It may be that in a given circumstance a mixture of conventional adaptive routes and less-adaptive non-conventional routes to $\operatorname{IgE}$ are operating simultaneously. For example, infection with a helminth produces not only high affinity antigen-specific IgE but also a lot of "non-specific" IgE and similarly NKG2D-dependent induction of IgE from stressed skin produces not only antigen-specific IgE to an antigen encountered simultaneously but also "non-specific" IgE (53). Analysis of $\operatorname{IgE}$ repertoires and the particular requirements for development of IgE-secreting B cells is needed to further elucidate conventional (via Th2) and non-conventional routes to IgE. This may also provide invaluable information as to what actually constitutes a host-protective response (against tissue stress, toxins, parasites) versus allergic Th2 immunity.

\section{IMMUNE SURVEILLANCE}

To address the role of EC-driven type 2 immunity in tissue immune surveillance it is useful to first define "immune surveillance." Immune surveillance refers to the capacity of the immune system to sense cellular dysregulation and respond by activating a stress response to restore homeostasis. This continued "quality control" mechanism has most commonly been applied to and studied in relation to cancer. The cancer immuosurveillance hypothesis was first proposed by Ehrlich in 1909 when he predicted that the immune system could repress or destroy the outgrowth of tumors that arise spontaneously on a continued basis (91). This proposal initiated a century of debate over the immune systems role in controlling neoplasia. The idea of a natural immune response against neoplasms or pre-malignant and dysregulated cells was revisited and expanded by Burnet and Thomas in the 1950s $(92,93)$. They proposed that lymphocytes form the basis of a "cancer immunosurveillance" process that protects immunocompetent hosts against primary tumor development. Although the hypothesis grew in recognition with the expansion of knowledge about the immune system and tumor-antigen recognition, the architects themselves pointed to "the problem with the idea of immunosurveillance is that it cannot be shown to exist in experimental animals" (94) - and it is of course rarely appreciated in a clinical setting. By the early 1990s, little attention was paid to the idea that natural immunity could control tumor establishment de novo. However, by the mid-1990s and onward several observations were made that rekindled the interest in this early aspect of tumor immunity [reviewed in Ref. (95)]. In short, the physiological importance of immune surveillance was well revealed by the pathological consequences of its failure: the neutralization of IFN $\gamma$ with antibodies (96) and later the use of mice lacking IFN $\gamma$ responsiveness was shown to enhance tumor growth (97). Lymphocytes were unequivocally proven to play an essential role in immune surveillance by seminal observations in $\mathrm{rag} 2^{-/-}$mice (98) and subsets of lymphocytes such as NK, NKT cells (99), and $\gamma \delta \mathrm{T}$ cells $(100)$ were shown to play prominent roles in the control of malignancy. These new data prompted a refinement of the cancer immunosurveillance concept (95) and an ongoing quest to understand the triggers and mechanistic action of this early and continuous immune response against altered self.

\section{ELICITORS AND EFFECTORS OF IMMUNE SURVEILLANCE}

Epithelial-derived cancers, called carcinomas, make up about $85 \%$ of all cancers. The epithelial barriers of our body surfaces are also where the majority of exogenous stresses and challenges occur. Both sterile and microbial insults are encountered daily at epithelial surfaces and prompt EC and immune activation. Cancer development is, however, a multifactorial and multistep process. Most solid cancers only emerge following a sequential accumulation of somatic mutations over many years, which eventually may overwhelm the barriers that normally restrain their growth and thus clonal expansion of transformed cells can occur. Cumulative mutational load, telomere dysfunction, and altered stromal milieu are all required before a solid tumor presents (101). Fortunately, numerous intrinsic and extrinsic tumor-supressor mechanisms exist to prevent the development and outgrowth of malignant cells and all cells continuously undergo these rigorous "health checks." The normal health control mechanisms can be triggered both by endogenous and exogenous stress and are executed by a cell-autonomous intrinsic surveillance system (such as delay in cell-cycle progression, repair of DNA-damage/genetic mutations, and induction of senescence or apoptosis) - and backed up by extrinsic immune surveillance mechanisms triggered by manifestations of EC dysregulation. The cell intrinsic responses to stress and the cell-extrinsic responses of the immune system are therefore intimately linked.

Damage-associated molecular patterns are mainly intracellular components of cells that are released or exposed upon physical or metabolic stress or cell death (102). For example ATP released from dying cells can act as a chemoattractant on macrophages drawing them to the stressed tissue (103). Extracellular ATP can bind to $\mathrm{P} 2$ purinergic receptors, which dependent on the cell engaged, can induce inflammatory (104) or anti-inflammatory (71) immune responses. Release of ROS or DNA from damaged cells can also powerfully initiate immune surveillance responses (105). Upon stress, ECs also rapidly and potently increase their synthesis of complement C3 (106), which due to its action on a multitude of innate and adaptive immune cells is likely to play a role in early 
immune surveillance, although its role in cancer as well as tissue homeostasis is as yet relatively unexplored.

In addition to the release of DAMPs, complement and cytokines/chemokines ECs can in response to numerous forms of cell-dysregulation dynamically alter cell-surface antigens to engage with receptors on innate and adaptive immune cells. Ligandreceptor interactions between ECs and tissue-resident immunocytes are thus important not only for homestatic interactions but are key regulators and elicitors of immune surveillance. One of the most important and best-characterized families of stress-induced EC ligands includes Rae-1, H60, and MULT1 (mouse), MICA, MICB and ULBPs (human). These are members of the larger family of MHC class Ib molecules and are reported upregulated on ECs by stresses such as heat-shock, UV-irradiation, DNA-damage, viral and bacterial infection, and autoimmunity. These unconventional MHC molecules engage the activating lectin-type receptor NKG2D, which is constitutively expressed by tissue-resident $\mathrm{T}$ cells and NK, NKT cells but is also expressed on $\mathrm{CD}^{+} \mathrm{T}$ cells and in some circumstances subsets of $\mathrm{CD}^{+} \mathrm{T}$ cells. The NKG2Dpathway has proven important in numerous settings of celldysregulation, such as cancer (107), infection (108), autoimmunity (109), and transplantation [reviewed in Ref. (110)], and its key role in immune surveillance is supported by the plethora of strategies tumors and viruses have adopted to evade it $(111,112)$. In relation to cancer, NKG2D-ligands are expressed by most epithelial tumors and the NKG2D-pathway is strongly associated with anti-tumor responses in both humans and mice (113). NKG2Dligands are often upregulated early upon cellular dysregulation or transformation, it has however been controversial whether immune cells could be activated by such self-moieties alone. By generating transgenic mice where an autologous NKG2D-ligand, Rae-1, could be upregulated on keratinocytes by administration of doxycycline it was shown that even in the absence of any overt microbial stress (or overt tissue/cellular dysregulation as in a tumor setting) engagement of NKG2D on the epidermal IELs (DETCs) activated these cells and caused profound changes in the local immune compartment (114). This demonstrates that resident immunocytes can recognize and act solely on alterations in autologous stress antigens and thus survey the "health-status" of a given EC, pre-malignancy. The data support the cancer immune surveillance theory as it was also shown that the tissue-resident IELs have a key role in host-protection against skin carcinogenesis (114). Afferent sensing is normally attributed to innate myeloid cells, perhaps particularly to DCs that are often viewed as the primary orchestrator of adaptive immunity. To highlight the capacity of tissue-resident $\mathrm{T}$ cells (as demonstrated by the epidermal $\gamma \delta \mathrm{T}$ cells discussed above) to perform an equivalent function as sensors of dysregulation, this mode of afferent sensing has been termed "lymphoid stress-surveillance" (115, 116). Lymphoid stress-surveillance may particularly be engaged in recognition of "stressed-self" and as such confer "beneficial autoimmune" responses in our body surface tissues. It is intriguing that NKG2D is expressed primarily, perhaps exclusively, by lymphoid cells ( $\gamma \delta \mathrm{T}, \mathrm{NKT}, \mathrm{CD}^{+} \alpha \beta \mathrm{T}$, and NK cells), suggesting that engagement of NKG2D could elicit an acute lymphocyte stress response to EC damage perhaps engaging different cells in different tissues.
In addition to the NKG2D-pathway, many other ligandreceptor pathways modulating epithelial-immune cell interactions and contributing to immune surveillance and tissue homeostasis are emerging. One such emerging family of regulators is the nectin and nectin-like (necl) proteins. Nectins are immunoglobulin-like cell-cell adhesion molecules involved in the formation of adherens junctions in ECs and fibroblast. Both nectin and the necl molecules play important roles not only in adhesion but also in migration, proliferation, and wound healing $(117,118)$. The group of receptors that engage these nectin molecules are therefore now being intensely studied in relation to cancer and immune surveillance (119). The major receptors that bind nectin and necl family members are DNAM-1 (CD226, PTA-1, TLiSA1), class I-restricted T cell-associated molecule (CRTAM), CD96, and TIGIT (WUCAM, VSIG9, Vstm3). All of these receptors are expressed on NK cells, $\gamma \delta \mathrm{T}$ cells and $\mathrm{CD} 8^{+} \alpha \beta \mathrm{T}$ cells and can mediate effector functions in these cells upon engagement. DNAM-1 ligands are frequently upregulated on tumor cells and have been reported to be regulated through the DNA-damage response pathway (120). Activation of DNAM-1 can evoke potent cytotoxicity in both T cells and NK cells (121) and control tumor growth (122). CRTAM binds necl2, which have been shown to regulate wound healing in the skin (118) and be involved in metastasis of human tumors (123). Expression and activation of CRTAM on immunocytes is likely highly important in early control of tissue homeostasis and cancer immune surveillance. In vitro studies have shown CRTAM to induce IFN $\gamma$ from $\mathrm{T}$ cells and in vivo ncl 2 expressing tumors have been shown to be controlled by $\mathrm{NK}$ and $\mathrm{CD} 8^{+} \mathrm{T}$ cells. Less is currently known about CD96 and TIGIT, but interestingly TIGIT appears to have an inhibitory function on NK and T cells (119).

Another example of an immune surveillance stimulator displayed by stressed ECs is the Coxsackie and adenovirus receptor (CAR). CAR is also a junctional adhesion molecule, it is upregulated on damaged ECs and potentially revealed when integrity of the tight junction is compromised. It binds junction adhesion molecule-like (JAML), which is expressed on neutrophils, tissue-resident $\gamma \delta \mathrm{T}$ cells, and to a lesser extent on monocytes and some activated $\mathrm{CD}^{+} \alpha \beta \mathrm{T}$ cells. Resident skin and intestinal $\gamma \delta$ T cells upregulate their expression of JAML upon tissue injury and binding of JAML to CAR lead to proliferation, cytokine, and growth factor production (124). Inhibiting costimulation of resident $\gamma \delta \mathrm{T}$ cells by blocking JAML significantly delayed wound healing, akin to the total absence of these resident T cells, suggesting that CAR-JAML interactions are important for initiation of immune surveillance and tissue homeostasis. Interestingly, it has been shown that interaction of JAML with CAR recruits the central cell signal transducer PI $3 \mathrm{~K}$, as is known for the $\alpha \beta \mathrm{T}$ cell costimulator CD28, further emphasizing JAMLs role as a costimulator for tissue-resident $\mathrm{T}$ cells with implications for immune surveillance of dysregulated ECs (125).

Similar to the role of CAR-JAML interactions between ECs and resident $\mathrm{T}$ cells, it has recently been shown that plexin-B2CD100 interactions are important for regulating the activity of IELs in both the skin and intestine $(126,127)$. CD100 (also know as Sema4D) is a member of the large family of semaphorin proteins. These proteins interact with plexins, which were first shown to play a fundamental role in the nervous system directing axon 
guidance. Intriguingly though, semaphorin-plexin interactions are also extensively involved in regulating immune responses and analysis of CD100-deficient animals have revealed a crucial role for this semaphorin in both humoral and cellular immunity (128). In relation to EC-immunocyte interactions, plexin-B2 is expressed on ECs in the epidermis and in the colon and interaction with CD100 on resident $\gamma \delta$ IELs promotes wound repair in the skin (126) and protects against dextran sulfate sodium (DSS)-induced colitis in the intestine (127). In both tissues, $\mathrm{CD} 100^{-/-}$mice failed to mount a proliferative EC response to tissue damage, which was attributable to the lack of activation and growth factor production by the $\gamma \delta$ IELs required to heal the epithelium.

Tissue-resident immunocytes are in a unique position to carry out a continued maintenance function such as tissue stresssurveillance. Innate immune cells have the capacity to recognize antigens that are displayed in tissues following a variety of stressors and can respond rapidly in large numbers without requiring clonal expansion. The early stages of an immune response - the afferent phase - are therefore conventionally ascribed to myeloid cells or NK cells. However, as highlighted above tissue-resident T cells can also be afferent sensors of cellular dysregulation. The importance of a tissue-specific resident population in cancer immune surveillance has nevertheless been difficult to verify. This was addressed experimentally by taking advantage of the unique tissue location of specific $\gamma \delta$ TCR-expressing IELs in the mouse, where the epidermal population of $\mathrm{V} \gamma 5 \mathrm{~V} \delta 1^{+}$IELs can be specifically knocked out (leaving all other $\mathrm{T}$ cell populations intact). These $v g 5 v d 1^{-/-}$ mice are significantly more susceptible to cutaneous carcinogenesis than wild-type mice, demonstrating a key role for resident tissue-specific IELs in cancer immune surveillance. Consistent with the cancer immune surveillance hypothesis the $\gamma \delta$ IEL act early and significantly suppress the development of papillomas but cannot suppress the progression from papilloma to carcinoma (114). Thus, myeloid cells, NK cells, and IELs all act as afferent sensors of dysregulation and initiators of immune surveillance in epithelial tissues. These cells can then also contribute to the downstream effector and regulatory phases of immunity. Clearly, both $\mathrm{CD}^{+}{ }^{+}$and $\mathrm{CD}^{+} \alpha \beta \mathrm{T}$ cells as well as B cells play important roles in cancer immune surveillance in the effector phase.

\section{FUNCTIONS AND MECHANISMS OF IMMUNE SURVEILLANCE}

The afferent phase of immune surveillance - the sensing of dysregulated self - applies to many other stresses than purely oncogenic stress. Thus the concept of immune surveillance not only pertains to cancer; accumulating evidence suggests that it can be more broadly applied to other non-malignant pathologies. For example, liver fibrosis, as a result of liver damage, is exacerbated when NK or NKT cells are depleted or the gene for perforin (required for cytotoxicity) is deleted as the stressed hepatic stellar cells cannot be controlled $(129,130)$. Stressed hepatic stellar cells express NKG2D-ligands upon damage, as described for ECs, facilitating their recognition by immune surveillance cells. Interestingly, natural activation of hepatic iNKT cells inhibits fibrosis whereas non-natural "over-stimulation" of iNKT cells appears to have the opposite effect and accelerate liver injury (129). Equally in the liver, tissue-resident macrophages have been shown to protect against ischemia reperfusion injury and be critical for tissue homeostasis (131).

Mice lacking normal resident IEL repertoires, such as $\mathrm{Tcrd}^{-/-}$ mice, develop spontaneous chronic dermatitis, which can only be downregulated when $T c r d^{-/-}$mice are reconstituted with the tissue-specific resident IEL (the V $\gamma 5 \mathrm{~V} \delta 1$ TCR-expressing epidermal DETC) (132). Interestingly, these $\mathrm{Tcrd}^{-/-}$mice also show a defect in the integrity of the epidermal barrier, as measured by hydration status and transepidermal water loss (TEWL). However, the epidermal barrier defect is obvious only upon environmental challenge, consistent with the notion that the IELs survey the health-status of the ECs and promote tissue homeostasis (133). Skin IELs were also the first $\mathrm{T}$ cells to be implicated in promoting EC growth. Closure of full-thickness skin wounds is significantly delayed in $T c r d^{-/-}$mice, and this is attributed to the skin IELs capacity to rapidly produce EC growth factors such as insulin-like growth factor-1 (IGF-1) and keratinocyte growth factors (KGF) $(134,135)$. Intriguingly, it has also been shown in humans that $\mathrm{T}$ cells isolated from healthy or acutely wounded skin actively produce EC growth factors and participate in wound repair, whereas $\mathrm{T}$ cells from patients with chronic wound-healing problems are anergic and unable to produce EC growth factors (136). Similarly, $\mathrm{Tcrd}^{-/-}$mice lacking the $\gamma \delta$ IEL population, which represents a major intestinal $\mathrm{T}$ cell population, are more susceptible to DSSinduced mucosal injury of the gut and demonstrate delayed tissue repair due to the lack of localized delivery of EC growth factors from the missing $\gamma \delta$ IEL compartment (137).

The examples above clearly demonstrate that immune surveillance is not only a mechanism to control the development and outgrowth of tumors but is also a key regulator of tissue homeostasis more generally [reviewed in Ref. (138)]. The implication of immune surveillance mechanisms in the maintenance and reestablishment of tissue homeostasis thus broadens its scope and it is likely that similar cell-extrinsic immune surveillance mechanisms are important at disease-initiating (pre-disease) stages in many pathophysiological settings other than cancer.

Immune surveillance can function by many (non-exclusive) mechanisms (Figure 2): (1) recognize and remove damaged, stressed, senescent, and (pre)-malignant cells, (2) remove damaging substances, waste, and dead cells, (3) facilitate re-establishment of homeostasis by repair mechanisms, (4) neutralize potential harmful environmental substances, or (5) dampen detrimental inflammatory reactions.

In relation to cancer immune surveillance, the main focus has been on type 1 immunity and cytotoxic mechanisms, both of which have overwhelming experimental support for playing a role in extrinsic tumor suppression. In both genetic and carcinogeninduced tumor models, cytotoxic molecules such as perforin and TRAIL, as well as NKG2D engagement, have repeatedly been shown to be important in tumor control. Likewise mice lacking type 1 molecules such as IFN $\gamma$, IFNGR, IL-12, or type I IFN receptors are significantly more susceptible to carcinogenesis in several models. Mice lacking IFN $\gamma$, perforin, TRAIL, functioning FasL or IL-12 responsiveness can also develop spontaneous tumors of variable origin [extensively reviewed in Ref. (139)].

However, the repair functions of immune surveillance are clearly also very important in the early phases of immune 


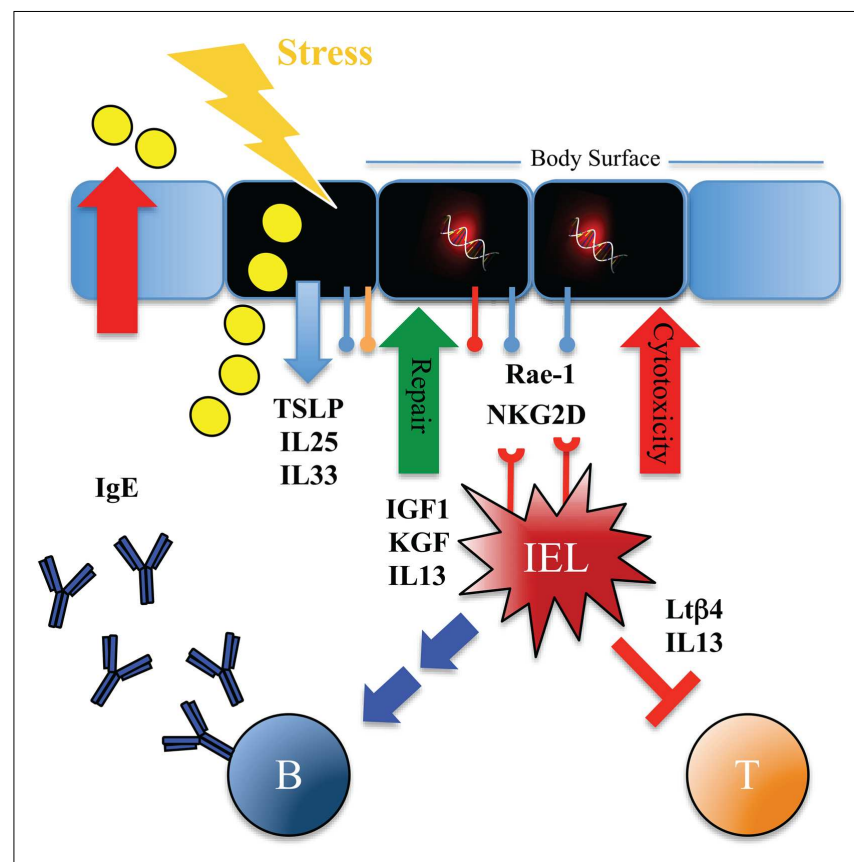

FIGURE 2 | Immune surveillance with type 2 immunity promotes tissue homeostasis and protects against carcinogenesis using numerous layers of control. Scheme illustrating possible mechanisms whereby tissue-resident IELs can provide rapid host-protective immune surveillance and re-establish tissue homeostasis at body surfaces. Tissue stress as imposed by mechanical disruption, injury, or exposure to noxious environmental substances such as chemicals, carcinogens, UV-irradiation or toxins prompts ECs to release IL-25, IL-33, and TSLP cytokines, and upregulate expression of stress-ligands such as Rae-1,CAR, and plexins. This activates the resident IELs and their responses include cytolytic effects, release of growth factors (for example IGF-1, KGF), dampening of $\alpha \beta$ T cell-mediated inflammation [for example by release of thymosin- $\beta 4$ lymphoid splice variant (LT $\beta 4$ )], rapid and potent production of IL-13, as well as promoting humoral IgE responses. Stress surveillance by IELs can thus recognize and remove damaged and possibly (pre-)malignant cells, promote tissue repair, and induce type 2 immunity, which in turn controls inflammation, expels or inactivates noxious substances, and promotes morphological tissue homeostasis.

surveillance. This is illustrated by the link between wounding and tumor development. It has been observed that tumors can develop at the site of chronic skin wounds or untreated mouth ulcers (140) and there are several case reports of lung metastasis at sites of accidental trauma (141). A clear illustration of the link between a defective wound-healing response and the development of cancer comes from patients with epidermolysis bullosa. These patients have mutations in genes encoding skin extracellular matrix components and suffer from chronic skin blistering and sores - and as a result of the chronic tissue damage are at increased risk of developing squamous cell carcinoma (142, 143). A diminished capacity to repair a damaged barrier can thus predispose to the development of cancer. Such associations between chronic damage/wounds and cancer as well as the histological similarities of wounds and tumors led to the often-cited phrase that "tumors are wounds that do not heal" (144).

The association between chronic wounds and development of cancer may of course not only pertain to the lack of repair per se but also to the onset of a detrimental chronic inflammation as a consequence. There is a close association between chronic inflammation and cancer, and once a malignant cell has escaped the early phase of immune surveillance, inflammation can exert prominent pro-carcinogenic effects (145). The tumorpromoting effects of inflammation are being intensively studied and are starting to have implications for the treatment of cancers $(145,146)$. An important feature of early tumor immune surveillance could thus be the release of anti-inflammatory products in the tissue. Stressed ECs promptly release many anti-inflammatory products such as IL-33, TSLP, and IL-25 - all with the propensity to drive anti-inflammatory type 2 immune responses. The role of such anti-inflammatory DAMPs and type 2 immunity in early cancer immune surveillance remains to be clarified but intriguingly when tumor-protective skin-resident IELs are activated by stressed ECs they promptly release high levels of IL-13 (53) (and Strid-J unpublished data). Interestingly, this IL-13 and a following production of IgE is dependent on engagement of NKG2D on the IELs (53), perhaps suggesting that the tumor-suppressive effect of NKG2D and skin-resident IELs may not solely be via cytotoxic/type 1-mediated immune surveillance mechanisms. The surprising association between NKG2D and anti-inflammatory type 2 immune responses (and $\operatorname{IgE}$ ) was recently corroborated in a model of allergic pulmonary inflammation, where mice lacking NKG2D were resistant to the induction of allergic inflammation and showed reduced Th2 and IgE responses (147). The association between a stress-sensor such as NKG2D, which has been intimately linked to anti-tumor responses, and induction of type 2 immunity demands a closer look at the role of early type 2 immunity in cancer immune surveillance. The possible role of such early type 2 responses in tissue homeostasis and immune surveillance of cancer as well as its possible pro- and anti-tumor growth functions are discussed in more detail below.

\section{ROLE OF TYPE 2 IMMUNITY IN TISSUE HOMEOSTASIS AND IMMUNE SURVEILLANCE}

What is known so far of the physiological role of type 2 responses is that their host-protection properties converge in different forms of barrier defenses (58). This seems logical as epithelial surfaces have a propensity to drive type 2 immunity (rather than type 1) upon non-invasive/non-penetrating challenge or stress and type 2 immune mediators are thus well poised to play a role in early immune surveillance as well as homeostatic tissue regulation. IL13 is the best-characterized inducer of mucus production and goblet cell hyperplasia in the respiratory and intestinal mucosa. In the skin, transgenic over-expression of IL-13 induces skin remodeling, which is primarily driven by TSLP (148). In both circumstances, hyperplasia results in improved resistance to damage and damaging substances at the body barrier either via production of mucus at the mucosal surfaces or thickening of the skin. IL-13 may also be involved in homeostatic EC differentiation/proliferation in the skin. Epidermal IELs, which are non-redundant for normal tissue homeostasis and wound-healing, are rapid and potent producers of IL-13 following skin challenge (UV-radiation, tape-stripping, NKG2D-ligand expression, and exposure to carcinogen) and mice deficient in IL-13 have delayed barrier repair following epidermal tape-stripping as measured by TEWL (Strid-J unpublished). 
Removal or expulsion is another host defense strategy induced by type 2 immunity, which can directly protect against noxious toxins or parasites, as well as limiting their systemic dissemination. The removal/expulsive actions of allergic and type 2 immunity through sneezing/coughing/itching/vomiting/diarrhea are partly induced by EC-derived mediators including TSLP, which acts directly on sensory neurons in the skin triggering itching (149), and by the effect of mast cell-derived histamine on smooth muscles. Type 2 immune mediators can also confer host-protection by inactivation, neutralization, and destruction of noxious substances. This is most notably shown by the requirement for mast cells in the detoxification of snake and bee venom (150) and the evidence that mast cell proteases can specifically attack snake venom at the structures required for toxicity and thereby neutralizing it (151). Recent data strongly suggest that IgE mediates or at least contributes to protection against venoms as for example the protective responses against re-challenge with high doses of bee venom is abrogated in mice lacking B cells, FceRI, or IgE $(56,57)$. It is likely that this protection is partly via the very rapid IgE-mediated degranulation of mast cells. Encapsulation and restriction is another layer of barrier defense regulated by type 2 mediators, which can help prevent the spread of noxious substances if elimination or expulsion has been insufficient. Endothelial leakage and exudate formation can be induced by mast cell-derived products and such local tissue edema may impede parasite invasion. For example it has been shown that the edema caused by IgE-mediated mast cell degranulation is important in the defense against macroparasites such as ticks (152). Another restriction mechanism, which may restrict the spread of noxious substance as well as macroparasites, involves sequestration through granuloma formation. Type 2 immune responses protect the host during infection with schistosomiasis by inducing granulomas that sequester the tissue-damaging toxins from the parasite eggs (153).

Perhaps most importantly, much of type 2 immunity seems dedicated to tissue repair and promoting tolerance to damage. Indeed, it has been hypothesized that type 2 immunity has evolved to direct innate wound repair mechanisms (154). The rationale for the induction of tissue repair as a part of type 2 immune defense is obvious. It may also explain the extreme urgency of some type 2 responses (which is not easily explained if directed only toward a slow replicating macroparasite), as damage control may well be more important than pathogen control. In evolutionary terms, it makes sense to be able to quickly expel or neutralize noxious substances as well as rapidly repair the life-essential body barrier. EC-derived cytokine alarmins and cell-ligands can activate and direct the resident tissue cells to promote repair responses; IELs rapidly sense stress and can produce growth factors locally in the absence of further inflammation and tissue-resident ILCs can amplify the type 2 response and produce amphiregulin. Indeed, depletion of ILC2 compromises lung epithelial barrier integrity (155) just as depletion of $\gamma \delta$ IEL compromises skin and gut epithelial integrity during homeostasis as well as delaying wound healing $(127,133,134)$. Almost all of the cells associated with type 2 immunity are also associated with the wound-healing response. Alternatively activated macrophages produce vascular endothelial growth factor (VEGF), arginase 1, and IGF-1; Eosinophils store preformed growth factors, matrix metalloproteinases, and lipid mediators, all of which can mediate wound healing (156). Amphiregulin is produced by mast cells following FceRI signaling, potentially also linking IgE responses to wound repair (157). In sum, the effects of type 2 immunity at our body surface tissues play important roles in eliminating, restricting, and neutralizing noxious environmental substances as well as repairing the damage caused and minimizing inflammation - as such this type of immunity is critical for tissue homeostasis and responses to challenges that have breached the epithelial barrier.

In terms of early cancer immune surveillance, the role of type 2 immunity has been little explored. However, the effects of rapid type 2 immune responses as outlined above could indeed play a prominent role in cancer immune surveillance. It has been demonstrated that the same tissue-resident IELs act as key components of tumor resistance and potent inducers of type 2 immunity and $\operatorname{IgE}$ antibodies $(53,114)$. The humoral component of this lymphoid stress-surveillance response may limit tissue damage by targeting noxious foreign substances, such as toxins that may be the root cause of the tissue dysregulation. The IgE effector response may promote toxin expulsion and limit their systemic dissemination. Simultaneously, the cellular response can direct cytotoxicity toward dysregulated cells as well as promoting repair of the damaged tissue and dampening inflammation (Figures 2 and 3). To limit the likelihood of cancer, it is clearly important to repair a wound or breached barrier quickly and efficiently as is demonstrated by the close association between chronic tissue damage and cancer. Less efficient wound repair may lead to inefficient immune surveillance against (pre-)malignant cells with damaged cells being allowed to stay longer in the tissue before being replaced. Additionally, slow repair of tissue damage may lead to inflammation, which as discussed can have potent pro-carcinogenic effects.

Although one can imagine a role for type 2 immunity and its regenerative capacity in early cancer immune surveillance this may indeed be a double-edged sword in further development of cancer (Figure 3). Failure of the type 2 response to adequately contain or eliminate the initiating substance may lead to a chronic wound-healing response and exacerbation of inflammation. Such continued tissue damage, repair, and regeneration may ultimately result in fibrosis. Fibrotic tissue is a highly permissive environment for tumor formation and it is also well established that continuous wound-healing responses and tumorigenesis are two processes that rely on similar molecular mechanisms (158). As such it is perhaps not surprising that the literature on type $2 / \operatorname{IgE}$ responses and cancer is somewhat bewildering.

\section{ROLE OF TYPE 2 IMMUNITY AND IgE IN CANCER}

Both positive and negative effects of type 2 immunity on tumor growth and carcinogenesis have been reported in the literature (Table 1). Contrasting results are clearly in part due to the differing experimental approaches and models but most likely also reflects the divergent roles that type 2 immunity may play at different stages of carcinogenesis and in different tissues. CD4 ${ }^{+} \mathrm{T}$ cell-derived IL-4 has been reported to induce granulocyte infiltration, thereby promoting tumor clearance (an action enhanced by IL-13), and conversely increase tumor cells' resistance to apoptosis by up-regulation of anti-apoptotic proteins (159). Many 


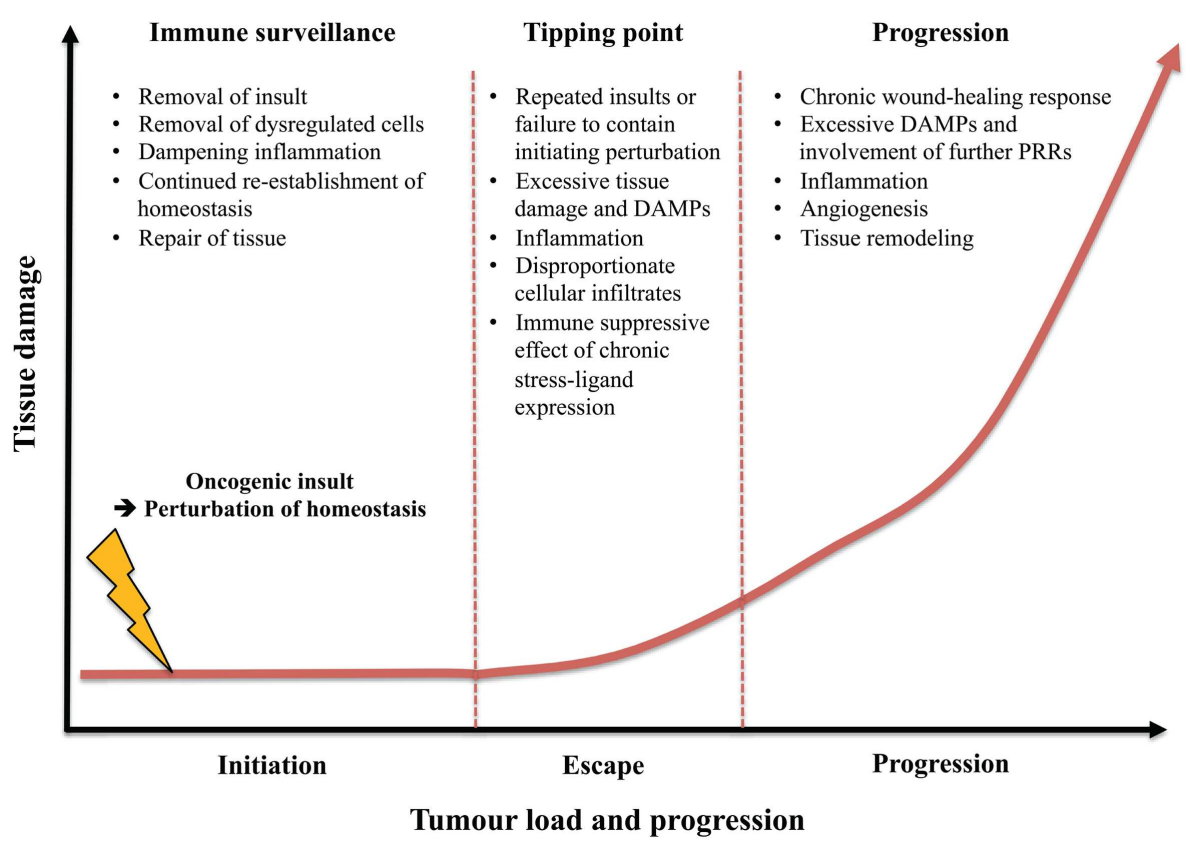

FIGURE 3 | Contrasting role of type 2 immunity in immune surveillance of early tissue dysregulation versus tumor progression. The type 2 component of immune surveillance may aid in host-protection against carcinogenesis at epithelial surfaces by removing the oncogenic insult, eliminating the dysregulated cells, dampening excessive inflammation, repairing tissue, re-establishing homeostasis, as well as improving resistance to future damage. However, following continuous perturbations, failure to eliminate the initial insult or dysregulated immune surveillance a tipping point may be reached where excessive tissue damage and DAMPs lead to inflammation, disproportionate cellular infiltrates, and escape from immune surveillance and tissue homeostasis. Once a certain level of tissue damage is reached, a perpetual type 2 response may be detrimental to the host by transitioning to aid carcinogenesis by promoting a chronic wound-healing response and fibrosis as well as supporting neo-angiogenesis. studies carried out in the 1990s and early 2000s demonstrated that tumors or tumor cell lines engineered to produce IL-4 would exhibit increased rejection and retarded growth in vivo; curiously a phenotype often dependent on $\mathrm{CD}^{+}$cytotoxic $\mathrm{T}$ cells (160-163). IL-10 has been reported to be both "pro-tumorigenic" by inhibiting tumor cell lysis by cytotoxic $\mathrm{T}$ cells and "antitumorigenic" by promoting NK-cell-mediated tumor clearance and inhibiting angiogenesis (164). The EC-derived cytokines IL33 and TSLP have been shown to enhance tumorigenesis by promoting epithelial-mesenchycmal transition (EMT) in organotypic culture of ex vivo carcinoma-associated fibroblasts (CAFs) and squamous cell carcinoma cells (165) and by enhancing Th2 inflammation (166). On the contrary TSLP has convincingly been shown in mouse in vivo models to be critically important for resistance to skin carcinogenesis $(35,36)$ establishing TSLP as a tumor suppressor in the skin. Many epithelial cancers express receptors for type 2 mediators such as IL-4 and IL-13, allowing for a direct effect on tumor growth, death, and proliferation that is independent of their effect on immunocytes (167). This perhaps also explains the likely divergent effects of type 2 immunity in early cancer immune surveillance versus in established tumors. Human breast and renal cancer cell lines treated with exogenous IL-13 in vitro demonstrate reduced proliferation (168170) - although an ovarian cancer line demonstrated enhanced invasive and enzyme (protease) activity (171) suggesting IL-13 aids primary tumor invasion and metastasis in this model. No doubt the heterogeneity of cancer cell lines and ex vivo tumors derived from patients and experimental animals clouds a consistent description of how potent type 2 cytokines may affect growth and immune surveillance of tumors in vivo. Cellular type 2 players, such as eosinophils, have an extensive description in the cancer literature, and have been shown to play a protective role against chemically induced tumors in vivo - and directly kill chemically induced fibrosarcomas in vitro (172), suggesting efficacious tissue immune surveillance. Mast cells frequently infiltrate the tumor microenvironment and are usually correlated with a poor prognosis in human cancers (173), although both tumor rejection and promotion has been attributed to them in the mouse. Interestingly, the ancient and highly conserved (174) immunoglobulin isotype IgE has been shown to play a significant role in immune surveillance of tumors. Since the 1990s IgE mAbs have been considered for cancer immunotherapy; particularly given IgE's extreme biological potency and presence of high and low affinity receptors on various effector cell types (175). Indeed, animals deficient in IgE show drastically altered susceptibility to cutaneous chemical carcinogenesis, and an altered tumor cytokine microenvironment (Dalessandri-T and Strid-J; unpublished). IgE-coated irradiated tumor cells has also been shown to generate protective, eosinophil, and $\mathrm{T}$ cell immunity to subsequently administered non-irradiated tumors (176). In addition, the type 2 immunoglobulin IgG1 has been reported to be potently tumoricidal when not "blocked" by competing IgG4 antibodies (177). 
Table 1 | Examples of type 2 cytokines and immunoglobulins influencing tumor pathology.

\begin{tabular}{|c|c|c|c|}
\hline Type 2 mediator & Experimental approach & Model & Tumor growth \\
\hline \multirow[t]{9}{*}{$\mathrm{IL}-4$} & \multirow{8}{*}{$\begin{array}{l}\text { Tumors engineered to produce IL-4, } \\
\text { IL-4 } \uparrow\end{array}$} & Primary murine renal cancer & $\downarrow$ Enhanced $\mathrm{CD}^{+} \mathrm{T}$ cell-dependent rejection (160) \\
\hline & & Injection of syngeneic tumor cell lines & $\downarrow$ Enhanced $\mathrm{CD}^{+} \mathrm{T}$ cell-dependent rejection (161) \\
\hline & & & $\uparrow$ Delayed primary tumor clearance, increased \\
\hline & & & secondary tumor development (178) \\
\hline & & & $\uparrow$ Reduced CD8 ${ }^{+}$T cell-mediated clearance (178) \\
\hline & & Primary murine adenocarcinoma & $\downarrow$ Enhanced $\mathrm{CD}^{+} \mathrm{T}$ cell-dependent and \\
\hline & & & eosinophil-mediated rejection (162) \\
\hline & & Vaccination with irradiated tumor cells & $\begin{array}{l}\downarrow \text { Enhanced } \mathrm{CD}^{+} \mathrm{T} \text { cell-dependent clearance of lung } \\
\text { metastases (163) }\end{array}$ \\
\hline & Exogenous rIL-4 treatment, IL-4 个 & $\begin{array}{l}\text { Prostate, breast and bladder cancer } \\
\text { cell lines }\end{array}$ & $\begin{array}{l}\uparrow \text { Enhanced resistance to apoptosis and } \\
\text { chemotherapeutic agents (159) }\end{array}$ \\
\hline \multirow[t]{6}{*}{ IL-13 } & $\begin{array}{l}\text { Tumors engineered to produce IL-13, } \\
\mathrm{IL}-13 \uparrow\end{array}$ & Injection of P815 mastocytoma cell line & $\begin{array}{l}\downarrow \text { Improved rejection and development of systemic } \\
\text { anti-tumor immunity (179) }\end{array}$ \\
\hline & \multirow[t]{4}{*}{ Exogenous IL-13 treatment, IL-13 $\uparrow$} & Ex vivo leukemic B blasts & $\begin{array}{l}\downarrow \text { Reduced proliferation and cell-cycle progression } \\
\text { assessed by DNA content (168) }\end{array}$ \\
\hline & & Human breast cancer cell line & $\begin{array}{l}\downarrow \text { Inhibition of estrogen-induced cell proliferation, } \\
\text { unchanged basal proliferation (169) }\end{array}$ \\
\hline & & Human renal carcinoma cell line & $\downarrow$ Reduced proliferation and colony formation (170) \\
\hline & & Ovarian cancer cell line & $\begin{array}{l}\uparrow \text { Increased MMP and AP-1-dependant invasion and } \\
\text { protease activity in matrigel invasion assay (171) }\end{array}$ \\
\hline & $\begin{array}{l}\text { Antibody-mediated IL-13 } \\
\text { neutralization, IL-13 } \downarrow\end{array}$ & Hodgkin lymphoma cell line & $\begin{array}{l}\downarrow \text { Decreased proliferation and STAT6 phosphorylation } \\
\text { (180) }\end{array}$ \\
\hline \multirow[t]{4}{*}{ IL-33 } & $\begin{array}{l}\text { IL-33 receptor knockout }\left(\mathrm{ST} 2^{-/-}\right) \text {, } \\
\text { IL-33-signaling } \downarrow\end{array}$ & $\begin{array}{l}\text { ST2-l- mammary carcinoma-bearing } \\
\text { mice }\end{array}$ & $\begin{array}{l}\downarrow \text { Attenuated tumor growth and metastasis, increased } \\
\text { number and cytotoxic activity of NK cells (181) }\end{array}$ \\
\hline & Exogenous IL-33 treatment, IL-33 $\uparrow$ & 4T1 cell line tumor-bearing mice & $\begin{array}{l}\uparrow \text { Reduced intra-tumoral tumoricidal NK cells, } \\
\text { increased splenic MDSCs and M2 macrophages (182) }\end{array}$ \\
\hline & $\begin{array}{l}\text { IL-33 co-admin, with HPV DNA } \\
\text { vaccine, IL-33 } \uparrow\end{array}$ & $\begin{array}{l}\text { TC-1 cell line (HPV-16 E7-positive) } \\
\text { tumor-bearing mice }\end{array}$ & $\begin{array}{l}\downarrow \text { Improved HPV antigen-specific CD4 and CD8T } \\
\text { cells, increased TC-1 regression (183) }\end{array}$ \\
\hline & Organotypic culture, IL-33 个 & $\begin{array}{l}\text { Ex vivo human carcinoma- } \\
\text { associated fibroblasts (CAFs) }\end{array}$ & $\begin{array}{l}\uparrow \text { CAFs promote carcinoma invasion via IL-33 signaling } \\
\text { and EMT induction (165) }\end{array}$ \\
\hline \multirow[t]{3}{*}{ TSLP } & $\begin{array}{l}\text { Antibody-mediated TSLP } \\
\text { neutralization, TSLP } \downarrow\end{array}$ & Murine breast tumor xenograft & $\downarrow$ Inhibition of tumor development (166) \\
\hline & $\begin{array}{l}\text { K14-TSLPTg or calcipotriol induced } \\
\text { TSLP, TSLP } \uparrow\end{array}$ & $\begin{array}{l}\text { DMBA/TPA chemical skin } \\
\text { carcinogenesis }\end{array}$ & $\begin{array}{l}\downarrow \text { Delayed tumor onset and significantly reduced } \\
\text { tumor number and growth (35) }\end{array}$ \\
\hline & $\begin{array}{l}\text { TSLP receptor knockout or TSLP } \\
\text { neutralization, TSLP-signaling } \downarrow\end{array}$ & Notchl/Notch2 receptor knockout & $\begin{array}{l}\uparrow \text { Loss of TSLP-signaling in Notch-deficient epidermis } \\
\text { leads to tumor formation (36) }\end{array}$ \\
\hline $\lg E$ & IgE-loaded tumor cell vaccine, $\lg \mathrm{E} \uparrow$ & $\begin{array}{l}\text { Post-vaccination challenge with RMA } \\
\text { lymphoma or MC38 adenocarcinoma }\end{array}$ & $\begin{array}{l}\downarrow \text { Improved protective eosinophil, } \mathrm{CD}^{+} \text {and } \mathrm{CD}^{+} \mathrm{T} \\
\text { cell responses to tumor challenge }(176,184)\end{array}$ \\
\hline $\operatorname{lgGl}$ & $\begin{array}{l}\text { Engineered tumor-antigen-specific } \\
\operatorname{lgG} 4, \operatorname{lgG} \mid \downarrow\end{array}$ & Human melanoma xenograft model & $\begin{array}{l}\uparrow \text { IgG4 blocked potent IgGl-mediated anti-tumor } \\
\text { effector functions (177) }\end{array}$ \\
\hline
\end{tabular}

\section{EPIDEMIOLOGICAL AND CLINICAL ASSOCIATIONS BETWEEN TYPE 2 IMMUNITY, IgE AND CANCER}

Associations between allergy history and cancer risk have been investigated in numerous epidemiological studies and their association is being defined in the nascent field of "AllergoOncology" (Table 2). Recent overviews of the epidemiological literature demonstrate that both potent inverse and positive associations exist, which point to complex underlying interactions as well as reflecting the heterogeneity of these diseases. Accordingly, although the relationship between cancer and allergy has intrigued researchers for decades, the biological nature of this association remains unclear. 
Table 2 | Proposed hypotheses explaining associations between type 2 immunity/allergy and cancer.

\begin{tabular}{|c|c|c|c|}
\hline Hypothesis & $\begin{array}{l}\text { Predicted allergy- } \\
\text { cancer relationship }\end{array}$ & $\begin{array}{l}\text { Predicted affected } \\
\text { tissue site }\end{array}$ & Proposed mechanisms \\
\hline $\begin{array}{l}\text { Antigenic stimulation or chronic } \\
\text { inflammation (185) }\end{array}$ & Positive, causal & All sites & $\begin{array}{l}\text { - Allergic inflammation and oxidative damage promote pro-tumorigenic } \\
\text { gene mutations } \\
\text { - Type 2-induced tissue remodeling and angiogenesis promotes tumor } \\
\text { growth and invasion }\end{array}$ \\
\hline Inappropriate Th2 skewing (186) & Positive, causal & All sites & $\begin{array}{l}\text { - Diversion away from protective cytolytic type } 1 \text { responses } \\
\text { - Non-protective IgE clonality, or poorly tumoricidal lgG4 class switching } \\
\text { with immunosuppressive IL-10 }\end{array}$ \\
\hline Immune surveillance (93) & Inverse, causal & All sites & $\begin{array}{l}\text { - Potent effector cells, including } \gamma \delta T \text { cells, mast cells and eosinophils } \\
\text { eradicate tumors } \\
\text { - Tumor-specific IgE potently cytolytic via ADCC } \\
\text { - Type } 2 \text { immunity repairs tissue damage and dampens inflammation } \\
\text { hereby restricting tumor formation }\end{array}$ \\
\hline Prophylaxis (55) & Inverse, causal & $\begin{array}{l}\text { Mucosal and } \\
\text { external surfaces }\end{array}$ & $\begin{array}{l}\text { - Tissue type } 2 \text { immunity removes or neutralizes noxious and potentially } \\
\text { carcinogenic environmental moieties before they cause genotoxicity } \\
\text { - Type } 2 \text { immunity restricts systemic dissemination of noxious } \\
\text { substances and enhances natural barrier defenses }\end{array}$ \\
\hline
\end{tabular}

Two hypotheses put forward to explain positive allergy-cancer associations are the "antigenic stimulation"/"chronic inflammation" hypothesis and the "inappropriate Th2 skewing" hypothesis (Table 2). The "antigenic stimulation" hypothesis was first proposed in the late 1980s (185) and has been reiterated numerous times, also termed the "chronic inflammation" hypothesis (186). This hypothesis proposes that inflammation associated with allergic disease establishes a tissue environment conducive to tumor growth. Indeed, more than 100 years ago a link between inflammation and cancer was first proposed by Virchow (146), who noted the presence of leukocytes in neoplastic tissues and suggested cancer originated at sites of chronic inflammation. Tissue damage with the release of DAMPs, chronic infection, and inflammation are all believed to contribute to the development of malignant disease. Mechanistically, cellular Th2-mediators such as macrophages promote oxidative damage through production of iNOS and hydrogen peroxide via the respiratory burst, increasing the likelihood of damage and mutation of tumor-suppressor genes or cell-cycle regulator genes. Tissue remodeling and pro-angiogenesis factors such as vasoactive mediators from tissue-resident mast cells and eosinophils, as well as VEGF, arginase and matrix metalloproteases released by macrophages, may promote local invasion of outgrowing tumors, and eventual metastasis with establishment of distal secondary loci worsening clinical outcome. Thus, the "antigenic stimulation/chronic inflammation" hypothesis predicts a positive relationship between allergic disease and cancer in any tissue site and this relationship is directly causal, i.e., inflammation secondary to or as a result of allergic disease directly promotes oncogenesis. The "inappropriate Th2 skewing" hypothesis (186) suggests that type 2 mediators - such as IL-4, IL-10, IL-13 may redirect tissue immunity away from a potently anti-tumor and cytolytic Th1 response, toward an ineffective Th2 response, where $\operatorname{IgE}$ is produced and directed toward allergens and not tumor-specific or tumor-associated antigens. Additionally, with production of immunomodulatory IL-10, Th2-immunogloublin IgG4 class-switch recombination is favored over IgE, the former being far less potently tumoricidal, further attenuating anti-tumor responses. This hypothesis therefore also predicts a positive relationship between allergic disease and cancer, in any tissue site, and this relationship is directly causal - skewing to type 2 responses that are non-protective and aids oncogenesis.

Two hypotheses put forward to explain inverse allergy-cancer associations are the "immune surveillance" hypothesis, and the "prophylaxis" hypothesis (Table 2). Prophylaxis was first proposed by Profet (55), and suggests that the symptoms and mechanisms of allergic disease serve to repel and clear potentially mutagenic substances at the external body surfaces before mutagenesis can occur; a coopted function of type 2 immunity which also serves to expel parasites and helminths. Itch induced by type 2 mediators such as TSLP, goblet cell hypersecretion of mucus, sneezing, coughing, vomiting, and diarrhea all act as repulsive mechanisms and are particularly common allergy symptoms. In additional to physical expulsion, type 2 cellular players directly deactivate noxious xenobiotics. In mice at least, mast cells have been shown to degrade venom components through release of carboxypeptidases (150), and IgE raised to a conserved component (and allergen) of many venoms is protective against a repeat exposure $(56,57)$. The unpleasantness of allergy symptoms also conditions the animal to avoid potentially carcinogenic triggers. Thus, the "prophylaxis" hypothesis predicts an inverse, causal relationship between allergic disease and cancer, particularly at the exposed body barrier surfaces. This hypothesis requires that moieties encountered at the body surfaces are directly carcinogenic, or are pro-carcinogens, and predicts that individuals with allergy symptoms should present with (i) lower levels of carcinogens in their blood and (ii) restrictive or obstructive disease at mucosal 
surfaces - or that treatment to reduce allergic symptoms results in greater vulnerability to cancer at those sites (187). These corollaries of the "prophylaxis" hypothesis have been poorly investigated. The "immune surveillance" hypothesis, first proposed by Burnet (93), also predicts an inverse allergy-cancer relationship and inverse associations are predicted at any body site. It suggests that allergy and atopic symptoms are indicative of an immune system that is generally hyper-responsive to challenge, and has enhanced immune surveillance capability. Potently cytolytic type 2 responses raised against tumor-associated or -specific antigens can rapidly eradicate dysregulated and proto-neoplastic cells; hence allergy symptoms are a fortuitous, albeit unpleasant, result of an individual's potent immune system, which also controls dysregulated cells and results in an inverse allergy-cancer relationship. Although the inverse allergy-cancer relationship proposed by the "immune surveillance" hypothesis was originally thought to be purely correlational, as argued in this review, type 2 immunity is also likely to play an important role in early immune surveillance in a direct casual manner by virtue of its ability to remove noxious substances, repair tissue damage and dampen initial inflammation.

In spite of many speculations and associations there is little evidence for a strong association between allergy and overall cancer risk (188). However, given that allergic disease occurs primarily at outer epithelial surfaces it is logical to examine the incidence of cancer at specific tissue sites, particularly those at which allergic disease is prevalent; such as the skin, respiratory, and gastrointestinal tracts. A recent large meta-analysis of more than 400 studies of relationships between allergy and cancer reported a preponderance of inverse allergy-cancer associations, and interestingly this was particularly strong for cancers of tissues that interface with the external environment, such as skin, mouth, throat, colon, and cervix (187). These results support the "prophylaxis" as well as the "immune surveillance" hypotheses. Intriguingly, while most studies investigate the link between specifically Type I allergic disease and cancer, a significant inverse association between contact (Type IV) hypersensitivity and breast and non-melanoma skin cancer has been reported, and the authors suggested these data support the "immune surveillance" hypothesis (189).

The large number of published association studies nevertheless often paints a conflicting picture, some of which may be due to methodological constraints. Most retrospective studies on allergy-cancer associations have investigated self-reported or clinician-diagnosed allergy, methodologies particularly prone to recollection and reporting bias (former) and subject selection bias (latter). Researchers have attempted to alleviate these concerns at least in part by discriminating subjects on the basis of physiological indices of allergic disease, such as serum IgE titers $(190,191)$ and skin-prick testing. Of course, serum total or allergen-specific IgE suffers less from human biases, but these are not a definite metric of allergic status in all individuals, all of the time; in addition this methodology potentially precludes the possibility of examining significant non-Type I hypersensitivities in the analysis. Another concern is that if variation between individual's allergy symptoms is due more to differences in individual's exposure to antigens and/or carcinogens (the environment as a confounding variable), rather than individual differences in immunity ("immune surveillance" hypothesis), then positive correlations between allergic symptoms and cancer may occur - even if the "prophylaxis" or "immune surveillance" hypotheses are true. Particularly, given that exposure to carcinogenic allergens (such as cigarette smoke or vehicle exhaust) results in increased cancer and allergic disease (187). In addition, the genetic and phenotypic heterogeneity of tumors, and the complex inflammatory niche in which they reside, may also confound epidemiological association studies.

\section{CONCLUDING REMARKS}

Epithelial cancers are products of a series of events starting with dysregulated and stressed ECs. It is now clear that challenges to ECs can trigger discrete pathways promoting the release of specific cytokines, chemokines, and expression of stress antigens on the EC surface. Together this can powerfully drive immune responses, initially from cells resident in the epithelial and subepithelial compartment. The initial response to EC challenge and damage is often a very rapid type 2 immune response. This may serve to remove or neutralize noxious challenging substances, clear waste, repair the tissue, dampen inflammation, and re-establish tissue homeostasis. It may also directly contribute to the elimination of damaged cells together with cytolytic mechanisms from resident IELs and other immunocytes. Rapid type 2 immune responses at body surfaces thus prominently contribute to immune surveillance of dysregulated ECs. Since epithelial dysregulation contributes notably to a multitude of inflammatory diseases, this may not only be important in control of (pre-)malignancy but could be important at disease-initiating stages in a variety of diseases.

Immune surveillance by its nature is mainly important in the initiation phase of tissue damage and tumor control - for maintenance of tissue homeostasis. The same effector molecules and mechanisms may play a very different role during the progression phase of tissue damage and tumor growth. Failure to eliminate the original damaging substance, damaged cells, or to repair the tissue may lead to a continual stress response with excessive release of DAMPs, persistent stress-ligand expression, inflammation, and a chronic wound-healing response and this may determine the transition point between beneficial and detrimental functions of type 2 immunity in the course of disease. Similarly, continual exposure to noxious environmental substances may eventually overwhelm the immune surveillance mechanisms keeping the damage in check and result in pathology or tumor growth. Further research is needed to study whether the balance between tumor cell growth and elimination may be tipped back upon immune manipulations aimed at enhancing naturally occurring immune surveillance.

\section{ACKNOWLEDGMENTS}

We thank colleagues within our laboratory and beyond for insightful discussions and especially Dr. Olga Sobolev for critical review of the manuscript. Apologies to colleagues whose work has inadvertently been overlooked or that were a victim of space constraints. We thank the Wellcome Trust for funding and declare no competing financial interests.

\section{REFERENCES}

\footnotetext{
1. Swamy M, Jamora C, Havran W, Hayday A. Epithelial decision makers: in search of the "epimmunome." Nat Immunol (2010) 11(8):656-65. doi:10.1038/ ni. 1905
} 
2. Nestle FO, Di Meglio P, Qin J-Z, Nickoloff BJ. Skin immune sentinels in health and disease. Nat Rev Immunol (2009) 9(10):679-91. doi:10.1038/nri2622

3. Jackson SP, Bartek J. The DNA-damage response in human biology and disease. Nature (2009) 461(7267):1071-8. doi:10.1038/nature08467

4. Wood LC, Elias PM, Calhoun C, Tsai JC, Grunfeld C, Feingold KR. Barrier disruption stimulates interleukin-1 alpha expression and release from a preformed pool in murine epidermis. J Invest Dermatol (1996) 106(3):397-403. doi:10.1111/1523-1747.ep12343392

5. Jerde TJ, Bushman W. IL-1 induces IGF-dependent epithelial proliferation in prostate development and reactive hyperplasia. Sci Signal (2009) 2(86):ra49. doi:10.1126/scisignal.2000338

6. Culig Z, Puhr M. Interleukin-6: a multifunctional targetable cytokine in human prostate cancer. Mol Cell Endocrinol (2012) 360(1-2):52-8. doi:10.1016/j.mce. 2011.05.033

7. Fort MM, Cheung J, Yen D, Li J, Zurawski SM, Lo S, et al. IL-25 induces IL4, IL-5, and IL-13 and Th2-associated pathologies in vivo. Immunity (2001) 15(6):985-95. doi:10.1016/S1074-7613(01)00243-6

8. Lee J, Ho WH, Maruoka M, Corpuz RT, Baldwin DT, Foster JS, et al. IL-17E, a novel proinflammatory ligand for the IL-17 receptor homolog IL-17Rh1. J Biol Chem (2001) 276(2):1660-4. doi:10.1074/jbc.M008289200

9. Owyang AM, Zaph C, Wilson EH, Guild KJ, McClanahan T, Miller HRP, et al. Interleukin 25 regulates type 2 cytokine-dependent immunity and limits chronic inflammation in the gastrointestinal tract. J Exp Med (2006) 203(4):843-9. doi:10.1084/jem.20051496

10. Zaph C, Du Y, Saenz SA, Nair MG, Perrigoue JG, Taylor BC, et al. Commensaldependent expression of IL-25 regulates the IL-23-IL-17 axis in the intestine. J Exp Med (2008) 205(10):2191-8. doi:10.1084/jem.20080720

11. Zaiss MM, Maslowski KM, Mosconi I, Guenat N, Marsland BJ, Harris NL. IL- $1 \beta$ suppresses innate IL-25 and IL-33 production and maintains helminth chronicity. PLoS Pathog (2013) 9(8):e1003531. doi:10.1371/journal.ppat. 1003531

12. Heneghan AF, Pierre JF, Gosain A, Kudsk KA. IL-25 improves luminal innate immunity and barrier function during parenteral nutrition. Ann Surg (2014) 259(2):394-400. doi:10.1097/SLA.0b013e318284f510

13. Angkasekwinai P, Park H, Wang Y-H, Wang Y-H, Chang SH, Corry DB, et al. Interleukin 25 promotes the initiation of proallergic type 2 responses. J Exp Med (2007) 204(7):1509-17. doi:10.1084/jem.20061675

14. Wang Y-H, Angkasekwinai P, Lu N, Voo KS, Arima K, Hanabuchi S, et al. IL-25 augments type 2 immune responses by enhancing the expansion and functions of TSLP-DC-activated Th2 memory cells. J Exp Med (2007) 204(8):1837-47. doi:10.1084/jem.20070406

15. Gregory LG, Jones CP, Walker SA, Sawant D, Gowers KHC, Campbell GA, et al. IL-25 drives remodelling in allergic airways disease induced by house dust mite. Thorax (2013) 68(1):82-90. doi:10.1136/thoraxjnl-2012-202003

16. Hams E, Armstrong ME, Barlow JL, Saunders SP, Schwartz C, Cooke G, et al. IL-25 and type 2 innate lymphoid cells induce pulmonary fibrosis. Proc Natl Acad Sci U S A (2014) 111(1):367-72. doi:10.1073/pnas.1315854111

17. Deleuran M, Hvid M, Kemp K, Christensen GB, Deleuran B, Vestergaard C. IL-25 induces both inflammation and skin barrier dysfunction in atopic dermatitis. Chem Immunol Allergy (2012) 96:45-9. doi:10.1159/000331871

18. Salimi M, Barlow JL, Saunders SP, Xue L, Gutowska-Owsiak D, Wang X, et al. A role for IL-25 and IL-33-driven type-2 innate lymphoid cells in atopic dermatitis. J Exp Med (2013) 210(13):2939-50. doi:10.1084/jem.20130351

19. Schmitz J, Owyang A, Oldham E, Song Y, Murphy E, McClanahan TK, et al. IL-33, an interleukin-1-like cytokine that signals via the IL-1 receptor-related protein ST2 and induces T helper type 2-associated cytokines. Immunity (2005) 23(5):479-90. doi:10.1016/j.immuni.2005.09.015

20. Komai-Koma M, Brombacher F, Pushparaj PN, Arendse B, McSharry C, Alexander J, et al. Interleukin-33 amplifies IgE synthesis and triggers mast cell degranulation via interleukin-4 in naïve mice. Allergy (2012) 67(9):1118-26. doi:10.1111/j.1398-9995.2012.02859.x

21. Humphreys NE, Xu D, Hepworth MR, Liew FY, Grencis RK. IL-33, a potent inducer of adaptive immunity to intestinal nematodes. J Immunol (2008) 180(4):2443-9. doi:10.4049/jimmunol.180.4.2443

22. Pastorelli L, Garg RR, Hoang SB, Spina L, Mattioli B, Scarpa M, et al. Epithelialderived IL-33 and its receptor ST2 are dysregulated in ulcerative colitis and in experimental Th1/Th2 driven enteritis. Proc Natl Acad Sci U S A (2010) 107(17):8017-22. doi:10.1073/pnas.0912678107
23. Fux M, Pecaric-Petkovic T, Odermatt A, Hausmann OV, Lorentz A, Bischoff SC, et al. IL-33 is a mediator rather than a trigger of the acute allergic response in humans. Allergy (2014) 69(2):216-22. doi:10.1111/all.12309

24. Imai Y, Yasuda K, Sakaguchi Y, Haneda T, Mizutani H, Yoshimoto T, et al. Skinspecific expression of IL-33 activates group 2 innate lymphoid cells and elicits atopic dermatitis-like inflammation in mice. Proc Natl Acad Sci U S A (2013) 110(34):13921-6. doi:10.1073/pnas.1307321110

25. Hueber AJ, Alves-Filho JC, Asquith DL, Michels C, Millar NL, Reilly JH, et al. IL-33 induces skin inflammation with mast cell and neutrophil activation. Eur J Immunol (2011) 41(8):2229-37. doi:10.1002/eji.201041360

26. Yanaba K, Yoshizaki A, Asano Y, Kadono T, Sato S. Serum IL-33 levels are raised in patients with systemic sclerosis: association with extent of skin sclerosis and severity of pulmonary fibrosis. Clin Rheumatol (2011) 30(6):825-30. doi:10.1007/s10067-011-1686-5

27. Yin H, Li X, Hu S, Liu T, Yuan B, Gu H, et al. IL-33 accelerates cutaneous wound healing involved in upregulation of alternatively activated macrophages. $\mathrm{Mol}$ Immunol (2013) 56(4):347-53. doi:10.1016/j.molimm.2013.05.225

28. Allakhverdi Z, Comeau MR, Jessup HK, Yoon B-RP, Brewer A, Chartier S, et al. Thymic stromal lymphopoietin is released by human epithelial cells in response to microbes, trauma, or inflammation and potently activates mast cells. J Exp Med (2007) 204(2):253-8. doi:10.1084/jem.20062211

29. Saenz SA, Taylor BC, Artis D. Welcome to the neighborhood: epithelial cellderived cytokines license innate and adaptive immune responses at mucosal sites. Immunol Rev (2008) 226:172-90. doi:10.1111/j.1600-065X.2008.00713.x

30. Zaph C, Troy AE, Taylor BC, Berman-Booty LD, Guild KJ, Du Y, et al. Epithelialcell-intrinsic IKK-beta expression regulates intestinal immune homeostasis. Nature (2007) 446(7135):552-6. doi:10.1038/nature05590

31. Ziegler SF, Artis D. Sensing the outside world: TSLP regulates barrier immunity. Nat Immunol (2010) 11(4):289-93. doi:10.1038/ni.1852

32. Al-Shami A, Spolski R, Kelly J, Keane-Myers A, Leonard WJ. A role for TSLP in the development of inflammation in an asthma model. J Exp Med (2005) 202(6):829-39. doi:10.1084/jem.20050199

33. Indra AK. Epidermal TSLP: a trigger factor for pathogenesis of atopic dermatitis. Expert Rev Proteomics (2013) 10(4):309-11. doi:10.1586/14789450.2013. 814881

34. Yoo J, Omori M, Gyarmati D, Zhou B, Aye T, Brewer A, et al. Spontaneous atopic dermatitis in mice expressing an inducible thymic stromal lymphopoietin transgene specifically in the skin. J Exp Med (2005) 202(4):541-9. doi:10.1084/jem.20041503

35. Demehri S, Turkoz A, Manivasagam S, Yockey LJ, Turkoz M, Kopan R. Elevated epidermal thymic stromal lymphopoietin levels establish an antitumor environment in the skin. Cancer Cell (2012) 22(4):494-505. doi:10.1016/j.ccr.2012. 08.017

36. Di Piazza M, Nowell CS, Koch U, Durham A-D, Radtke F. Loss of cutaneous TSLP-dependent immune responses skews the balance of inflammation from tumor protective to tumor promoting. Cancer Cell (2012) 22(4):479-93. doi:10.1016/j.ccr.2012.08.016

37. Jiang J, Hui C-C. Hedgehog signaling in development and cancer. Dev Cell (2008) 15(6):801-12. doi:10.1016/j.devcel.2008.11.010

38. Furmanski AL, Saldana JI, Ono M, Sahni H, Paschalidis N, D'Acquisto F, et al. Tissue-derived hedgehog proteins modulate Th differentiation and disease. J Immunol (2013) 190(6):2641-9. doi:10.4049/jimmunol.1202541

39. Kim J, Myers AC, Chen L, Pardoll DM, Truong-Tran Q-A, Lane AP, et al. Constitutive and inducible expression of b7 family of ligands by human airway epithelial cells. Am J Respir Cell Mol Biol (2005) 33(3):280-9. doi:10.1165/ rcmb.2004-01290C

40. Bas A, Swamy M, Abeler-Dörner L, Williams G, Pang DJ, Barbee SD, et al. Butyrophilin-like 1 encodes an enterocyte protein that selectively regulates functional interactions with T lymphocytes. Proc Natl Acad Sci U S A (2011) 108(11):4376-81. doi:10.1073/pnas.1010647108

41. Boyden LM, Lewis JM, Barbee SD, Bas A, Girardi M, Hayday AC, et al. Skint1, the prototype of a newly identified immunoglobulin superfamily gene cluster, positively selects epidermal $\gamma \delta$ T cells. Nat Genet (2008) 40(5):656-62. doi:10.1038/ng.108

42. Turchinovich G, Hayday AC. Skint-1 identifies a common molecular mechanism for the development of interferon- $\gamma$-secreting versus interleukin-17secreting $\gamma \delta$ T cells. Immunity (2011) 35(1):59-68. doi:10.1016/j.immuni.2011. 04.018 
43. Rölle A, Mousavi-Jazi M, Eriksson M, Odeberg J, Söderberg-Nauclér C, Cosman $\mathrm{D}$, et al. Effects of human cytomegalovirus infection on ligands for the activating NKG2D receptor of NK cells: up-regulation of UL16-binding protein (ULBP) 1 and ULBP2 is counteracted by the viral UL16 protein. J Immunol (2003) 171(2):902-8. doi:10.4049/jimmunol.171.2.902

44. Raulet DH, Gasser S, Gowen BG, Deng W, Jung H. Regulation of ligands for the NKG2D activating receptor. Annu Rev Immunol (2013) 31(1):413-41. doi:10.1146/annurev-immunol-032712-095951

45. Jung H, Hsiung B, Pestal K, Procyk E, Raulet DH. RAE-1 ligands for the NKG2D receptor are regulated by E2F transcription factors, which control cell cycle entry. J Exp Med (2012) 209(13):2409-22. doi:10.1084/jem.20120565

46. Vantourout P, Hayday A. Six-of-the-best: unique contributions of $\gamma \delta$ T cells to immunology. Nat Rev Immunol (2013) 13(2):88-100. doi:10.1038/nri3384

47. Cheroutre H, Lambolez F, Mucida D. The light and dark sides of intestinal intraepithelial lymphocytes. Nat Rev Immunol (2011) 11(7):445-56. doi:10. 1038/nri3007

48. Gebhardt T, Wakim LM, Eidsmo L, Reading PC, Heath WR, Carbone FR. Memory $\mathrm{T}$ cells in nonlymphoid tissue that provide enhanced local immunity during infection with herpes simplex virus. Nat Immunol (2009) 10(5):524-30. doi:10.1038/ni.1718

49. Jiang X, Clark RA, Liu L, Wagers AJ, Fuhlbrigge RC, Kupper TS. Skin infection generates non-migratory memory $\mathrm{CD} 8+\mathrm{T}(\mathrm{RM})$ cells providing global skin immunity. Nature (2012) 483(7388):227-31. doi:10.1038/nature10851

50. Eyerich S, Eyerich K, Pennino D, Carbone T, Nasorri F, Pallotta S, et al. Th22 cells represent a distinct human $\mathrm{T}$ cell subset involved in epidermal immunity and remodeling. J Clin Invest (2009) 119(12):3573-85. doi:10.1172/JCI40202

51. Cella M, Fuchs A, Vermi W, Facchetti F, Otero K, Lennerz JKM, et al. A human natural killer cell subset provides an innate source of IL-22 for mucosal immunity. Nature (2008) 457(7230):722-5. doi:10.1038/nature07537

52. Björkström NK, Kekäläinen E, Mjösberg J. Tissue-specific effector functions of innate lymphoid cells. Immunology (2013) 139(4):416-27. doi:10.1111/imm. 12098

53. Strid J, Sobolev O, Zafirova B, Polic B, Hayday A. The intraepithelial T cell response to NKG2D-ligands links lymphoid stress surveillance to atopy. Science (2011) 334(6060):1293-7. doi:10.1126/science.1211250

54. Harris N, Gause WC. To B or not to B: B cells and the Th2-type immune response to helminths. Trends Immunol (2011) 32(2):80-8. doi:10.1016/j.it. 2010.11.005

55. Profet M. The function of allergy: immunological defense against toxins. $Q$ Rev Biol (1991) 66(1):23-62. doi:10.1086/417049

56. Marichal T, Starkl P, Reber LL, Kalesnikoff J, Oettgen HC, Tsai M, et al. A beneficial role for immunoglobulin in host defense against honeybee venom. Immunity (2013) 39(5):963-75. doi:10.1016/j.immuni.2013.10.005

57. Palm NW, Rosenstein RK, Yu S, Schenten DD, Florsheim E, Medzhitov R. Bee venom phospholipase A2 induces a primary type 2 response that is dependent on the receptor ST2 and confers protective immunity. Immunity (2013) 39(5):976-85. doi:10.1016/j.immuni.2013.10.006

58. Palm NW, Rosenstein RK, Medzhitov R. Allergic host defences. Nature (2012) 484(7395):465-72. doi:10.1038/nature1 1047

59. Gutierrez DA, Rodewald H-R. A sting in the tale of Th2 immunity. Immunity (2013) 39(5):803-5. doi:10.1016/j.immuni.2013.10.015

60. Traidl-Hoffmann C, Jakob T, Behrendt H. Determinants of allergenicity J Allergy Clin Immunol (2009) 123(3):558-66. doi:10.1016/j.jaci.2008.12.003

61. Kool M, Lambrecht BN. Alum adjuvant boosts adaptive immunity by inducing uric acid and activating inflammatory dendritic cells. J Exp Med (2008) 205(4):869-82. doi:10.1084/jem.20071087

62. Fukuyama T, Tajima Y, Ueda H, Hayashi K, Shutoh Y, Saito TR, et al. Investigation of the chemical-induced selective type II (TH2) allergic response in mice: effect of the length of the sensitizing phase. Jimmunotoxicol (2009) 6(2):75-83. doi:10.1080/15476910902891319

63. Dearman RJ, Basketter DA, Kimber I. Selective induction of type 2 cytokines following topical exposure of mice to platinum salts. Food Chem Toxicol (1998) 36(3):199-207. doi:10.1016/S0278-6915(97)00143-9

64. Jotwani R, Pulendran B, Agrawal S, Cutler CW. Human dendritic cells respond to Porphyromonas gingivalis LPS by promoting a Th2 effector response in vitro. Eur J Immunol (2003) 33(11):2980-6. doi:10.1002/eji.200324392

65. Salgame P, Yap GS, Gause WC. Effect of helminth-induced immunity on infections with microbial pathogens. Nat Immunol (2013) 14(11):1118-26. doi:10.1038/ni.2736
66. Bryson K, Besteiro S, McGachy HA, Coombs GH, Mottram JC, Alexander J. Overexpression of the natural inhibitor of cysteine peptidases in Leishmania mexicana leads to reduced virulence and a Th1 response. Infect Immun (2009) 77(7):2971-8. doi:10.1128/IAI.00558-08

67. Kuroda E, Ishii KJ, Uematsu S, Ohata K, Coban C, Akira S, et al. Silica crystals and aluminum salts regulate the production of prostaglandin in macrophages via NALP3 inflammasome-independent mechanisms. Immunity (2011) 34(4):514-26. doi:10.1016/j.immuni.2011.03.019

68. Mishra PK, Wu W, Rozo C, Hallab NJ, Benevenia J, Gause WC. Micrometersized titanium particles can induce potent Th2-type responses through TLR4-independent pathways. J Immunol (2011) 187(12):6491-8. doi:10.4049/ jimmunol.1101392

69. Kool M, Willart MAM, van Nimwegen M, Bergen I, Pouliot P, Virchow JC, et al. An unexpected role for uric acid as an inducer of $\mathrm{T}$ helper 2 cell immunity to inhaled antigens and inflammatory mediator of allergic asthma. Immunity (2011) 34(4):527-40. doi:10.1016/j.immuni.2011.03.015

70. Marichal T, Ohata K, Bedoret D, Mesnil C, Sabatel C, Kobiyama K, et al. DNA released from dying host cells mediates aluminum adjuvant activity. Nat Med (2011) 17(8):996-1002. doi:10.1038/nm.2403

71. Kouzaki H, Iijima K, Kobayashi T, O’Grady SM, Kita H. The danger signal, extracellular ATP, is a sensor for an airborne allergen and triggers IL33 release and innate Th2-type responses. J Immunol (2011) 186(7):4375-87. doi:10.4049/jimmunol.1003020

72. Tang H, Cao W, Kasturi SP, Ravindran R, Nakaya HI, Kundu K, et al. The T helper type 2 response to cysteine proteases requires dendritic cell-basophil cooperation via ROS-mediated signaling. Nat Immunol (2010) 11(7):608-17. doi:10.1038/ni.1883

73. Moghaddam AE, Gartlan KH, Kong L, Sattentau QJ. Reactive carbonyls are a major Th2-inducing damage-associated molecular pattern generated by oxidative stress. J Immunol (2011) 187(4):1626-33. doi:10.4049/jimmunol. 1003906

74. Chavanas S, Bodemer C, Rochat A, Hamel-Teillac D, Ali M, Irvine AD, et al. Mutations in SPINK5, encoding a serine protease inhibitor, cause Netherton syndrome. Nat Genet (2000) 25(2):141-2. doi:10.1038/75977

75. Walley AJ, Chavanas S, Moffatt MF, Esnouf RM, Ubhi B, Lawrence R, et al. Gene polymorphism in Netherton and common atopic disease. Nat Genet (2001) 29(2):175-8. doi:10.1038/ng728

76. Briot A, Deraison C, Lacroix M, Bonnart C, Robin A, Besson C, et al. Kallikrein 5 induces atopic dermatitis-like lesions through PAR2-mediated thymic stromal lymphopoietin expression in Netherton syndrome. J Exp Med (2009) 206(5):1135-47. doi:10.1084/jem.20082242

77. Fritz JH, Le Bourhis L, Sellge G, Magalhaes JG, Fsihi H, Kufer TA, et al. Nod1mediated innate immune recognition of peptidoglycan contributes to the onset of adaptive immunity. Immunity (2007) 26(4):445-59. doi:10.1016/j.immuni. 2007.03.009

78. Magalhaes JG, Fritz JH, Le Bourhis L, Sellge G, Travassos LH, Selvanantham T, et al. Nod2-dependent Th2 polarization of antigen-specific immunity. J Immunol (2008) 181(11):7925-35. doi:10.4049/jimmunol.181.11.7925

79. Magalhaes JG, Rubino SJ, Travassos LH, Le Bourhis L, Duan W, Sellge G, et al. Nucleotide oligomerization domain-containing proteins instruct $\mathrm{T}$ cell helper type 2 immunity through stromal activation. Proc Natl Acad Sci U S A (2011) 108(36):14896-901. doi:10.1073/pnas.1015063108

80. Eisenbarth SC, Piggott DA, Huleatt JW, Visintin I, Herrick CA, Bottomly K. Lipopolysaccharide-enhanced, Toll-like receptor 4-dependent $\mathrm{T}$ helper cell type 2 responses to inhaled antigen. J Exp Med (2002) 196(12):1645-51. doi: $10.1084 /$ jem. 20021340

81. Tan AM, Chen HC, Pochard P, Eisenbarth SC, Herrick CA, Bottomly HK. TLR4 signaling in stromal cells is critical for the initiation of allergic Th2 responses to inhaled antigen. J Immunol (2010) 184(7):3535-44. doi:10.4049/jimmunol. 0900340

82. Agrawal S, Agrawal A, Doughty B, Gerwitz A, Blenis J, Van Dyke T, et al. Cutting edge: different toll-like receptor agonists instruct dendritic cells to induce distinct $T h$ responses via differential modulation of extracellular signalregulated kinase-mitogen-activated protein kinase and c-Fos. J Immunol (2003) 171(10):4984-9. doi:10.4049/jimmunol.171.10.4984

83. Hammad H, Chieppa M, Perros F, Willart MA, Germain RN, Lambrecht BN. House dust mite allergen induces asthma via Toll-like receptor 4 triggering of airway structural cells. Nat Med (2009) 15(4):410-6. doi:10.1038/ nm.1946 
84. Schmidt M, Raghavan B, Müller V, Vogl T, Fejer G, Tchaptchet S, et al. Crucial role for human Toll-like receptor 4 in the development of contact allergy to nickel. Nat Immunol (2010) 11(9):814-9. doi:10.1038/ni.1919

85. Wen L, Roberts SJ, Viney JL, Wong FS, Mallick C, Findly RC, et al. Immunoglobulin synthesis and generalized autoimmunity in mice congenitally deficient in alpha beta(+) T cells. Nature (1994) 369(6482):654-8. doi:10.1038/369654a0

86. Wen L, Pao W, Wong FS, Peng Q, Craft J, Zheng B, et al. Germinal center formation, immunoglobulin class switching, and autoantibody production driven by "non alpha/beta" T cells. J Exp Med (1996) 183(5):2271-82. doi:10.1084/jem.183.5.2271

87. Aguado E, Richelme S, Nuñez-Cruz S, Miazek A, Mura A-M, Richelme M, et al. Induction of T helper type 2 immunity by a point mutation in the LAT adaptor. Science (2002) 296(5575):2036-40. doi:10.1126/science.1069057

88. Qi Q, Xia M, Hu J, Hicks E, Iyer A, Xiong N, et al. Enhanced development of $\mathrm{CD} 4+$ gammadelta $\mathrm{T}$ cells in the absence of Itk results in elevated IgE production. Blood (2009) 114(3):564-71. doi:10.1182/blood-2008-12-196345

89. Felices M, Yin CC, Kosaka Y, Kang J, Berg LJ. Tec kinase Itk in gamma delta T cells is pivotal for controlling IgE production in vivo. Proc Natl Acad Sci U S A (2009) 106(20):8308-13. doi:10.1073/pnas.0808459106

90. McCoy KD, Harris NL, Diener P, Hatak S, Odermatt B, Hangartner L, et al. Natural IgE production in the absence of MHC class II cognate help. Immunity (2006) 24(3):329-39. doi:10.1016/j.immuni.2006.01.013

91. Ehrlich P. Über den jetzigen Stand der Karzinomforschung. Ned Tijdschr Geneeskd (1909) 5:273-90.

92. Burnet M. Cancer; a biological approach. I. The processes of control. Br Med J (1957) 1(5022):779-86. doi:10.1136/bmj.1.5022.779

93. Burnet M. Cancer: a biological approach. III. Viruses associated with neoplastic conditions. IV. Practical applications. Br Med J (1957) 1(5023):841-7. doi:10.1136/bmj.1.5023.841

94. Thomas L. On immunosurveillance in human cancer. Yale J Biol Med (1982) 55(3-4):329-33.

95. Dunn GP, Old LJ, Schreiber RD. The three Es of cancer immunoediting. Annu Rev Immunol (2004) 22(1):329-60. doi:10.1146/annurev.immunol.22.012703. 104803

96. Dighe AS, Richards E, Old LJ, Schreiber RD. Enhanced in vivo growth and resistance to rejection of tumor cells expressing dominant negative IFN gamma receptors. Immunity (1994) 1(6):447-56. doi:10.1016/1074-7613(94)90087-6

97. Kaplan DH, Shankaran V, Dighe AS, Stockert E, Aguet M, Old LJ, et al. Demonstration of an interferon gamma-dependent tumor surveillance system in immunocompetent mice. Proc Natl Acad Sci U S A (1998) 95(13):7556-61. doi:10.1073/pnas.95.13.7556

98. Shankaran V, Ikeda H, Bruce AT, White JM. IFN $\gamma$ and lymphocytes prevent primary tumour development and shape tumour immunogenicity. Nature (2001) 410(6832):1107-11. doi:10.1038/35074122

99. Smyth MJ, Thia KY, Street SE, Cretney E, Trapani JA, Taniguchi M, et al. Differential tumor surveillance by natural killer (NK) and NKT cells. J Exp Med (2000) 191(4):661-8. doi:10.1084/jem.191.4.661

100. Girardi M, Oppenheim DE, Steele CR, Lewis JM, Glusac E, Filler R, et al. Regulation of cutaneous malignancy by gamma delta T cells. Science (2001) 294(5542):605-9. doi:10.1126/science.1063916

101. DePinho RA. The age of cancer. Nature (2000) 408(6809):248-54. doi:10.1038/ 35041694

102. Matzinger P. The danger model: a renewed sense of self. Science (2002) 296(5566):301-5. doi:10.1126/science.1071059

103. Chao MP, Majeti R, Weissman IL. Programmed cell removal: a new obstacle in the road to developing cancer. Nat Rev Cancer (2012) 12(1):58-67. doi:10.1038/nrc3171

104. Ma Y, Galluzzi L, Zitvogel L, Kroemer G. Autophagy and cellular immune responses. Immunity (2013) 39(2):211-27. doi:10.1016/j.immuni.2013.07.017

105. Zitvogel L, Kepp O, Galluzzi L, Kroemer G. Inflammasomes in carcinogenesis and anticancer immune responses. Nat Immunol (2012) 13(4):343-51. doi:10.1038/ni.2224

106. Schonthaler HB, Guinea-Viniegra J, Wculek SK, Ruppen I, Ximénez-Embún P, Guío-Carrión A, et al. S100A8-S100A9 protein complex mediates psoriasis by regulating the expression of complement factor C3. Immunity (2013) 39(6):1171-81. doi:10.1016/j.immuni.2013.11.011

107. Ullrich E, Koch J, Cerwenka A, Steinle A. New prospects on the NKG2D/NKG2DL system for oncology. Oncoimmunology (2013) 2(10):e26097. doi:10.4161/onci.26097
108. Cerwenka A, Lanier LL. NKG2D ligands: unconventional MHC class I-like molecules exploited by viruses and cancer. Tissue Antigens (2003) 61(5):335-43. doi:10.1034/j.1399-0039.2003.00070.x

109. Van Belle TL, von Herrath MG. The role of the activating receptor NKG2D in autoimmunity. Mol Immunol (2009) 47(1):8-11. doi:10.1016/j.molimm.2009. 02.023

110. Suárez-Alvarez B, López-Vázquez A, Baltar JM, Ortega F, López-Larrea C. Potential role of NKG2D and its ligands in organ transplantation: new target for immunointervention. Am J Transplant (2009) 9(2):251-7. doi:10.1111/ j.1600-6143.2008.02526.x

111. Groh V, Wu J, Yee C, Spies T. Tumour-derived soluble MIC ligands impair expression of NKG2D and T-cell activation. Nature (2002) 419(6908):734-8. doi:10.1038/nature01112

112. Lodoen MB, Lanier LL. Viral modulation of NK cell immunity. Nat Rev Microbiol (2005) 3(1):59-69. doi:10.1038/nrmicro1066

113. Champsaur M, Lanier LL. Effect of NKG2D ligand expression on host immune responses. Immunol Rev (2010) 235(1):267-85. doi:10.1111/j.0105-2896.2010. 00893.x

114. Strid J, Roberts SJ, Filler RB, Lewis JM, Kwong BY, Schpero W, et al. Acute upregulation of an NKG2D ligand promotes rapid reorganization of a local immune compartment with pleiotropic effects on carcinogenesis. Nat Immunol (2008) 9(2):146-54. doi:10.1038/ni1556

115. Strid J, Tigelaar RE, Hayday AC. Skin immune surveillance by T cells - a new order? Semin Immunol (2009) 21(3):110-20. doi:10.1016/j.smim.2009.03.002

116. Hayday AC. Gammadelta T cells and the lymphoid stress-surveillance response. Immunity (2009) 31(2):184-96. doi:10.1016/j.immuni.2009.08.006

117. Takai Y, Irie K, Shimizu K, Sakisaka T, Ikeda W. Nectins and nectin-like molecules: roles in cell adhesion, migration, and polarization. Cancer Sci (2003) 94(8):655-67. doi:10.1111/j.1349-7006.2003.tb01499.x

118. Giangreco A, Jensen KB, Takai Y, Miyoshi J, Watt FM. Necl2 regulates epidermal adhesion and wound repair. Development (2009) 136(20):3505-14. doi:10.1242/dev.038232

119. Chan CJ, Andrews DM, Smyth MJ. Receptors that interact with nectin and nectin-like proteins in the immunosurveillance and immunotherapy of cancer. Curr Opin Immunol (2012) 24(2):246-51. doi:10.1016/j.coi.2012.01.009

120. Soriani A, Zingoni A, Cerboni C, Iannitto ML, Ricciardi MR, Di Gialleonardo $\mathrm{V}$, et al. ATM-ATR-dependent up-regulation of DNAM-1 and NKG2D ligands on multiple myeloma cells by therapeutic agents results in enhanced NKcell susceptibility and is associated with a senescent phenotype. Blood (2009) 113(15):3503-11. doi:10.1182/blood-2008-08-173914

121. Shibuya A, Campbell D, Hannum C, Yssel H, Franz-Bacon K, McClanahan T, et al. DNAM-1, a novel adhesion molecule involved in the cytolytic function of T lymphocytes. Immunity (1996) 4(6):573-81. doi:10.1016/S1074-7613(00) 70060-4

122. Ramsbottom KM, Hawkins ED, Shimoni R, McGrath M, Chan CJ, Russell SM, et al. Cutting edge: DNAX accessory molecule 1-deficient CD8+ T cells display immunological synapse defects that impair antitumor immunity. J Immunol (2014) 192(2):553-7. doi:10.4049/jimmunol.1302197

123. Takahashi Y, Iwai M, Kawai T, Arakawa A, Ito T, Sakurai-Yageta M, et al. Aberrant expression of tumor suppressors CADM1 and 4.1B in invasive lesions of primary breast cancer. Breast Cancer (2012) 19(3):242-52. doi:10.1007/ s12282-011-0272-7

124. Witherden DA, Verdino P, Rieder SE, Garijo O, Mills RE, Teyton L, et al. The junctional adhesion molecule JAML is a costimulatory receptor for epithelial gamma delta T cell activation. Science (2010) 329(5996):1205-10. doi:10.1126/science. 1192698

125. Verdino P, Witherden DA, Havran WL, Wilson IA. The molecular interaction of CAR and JAML recruits the central cell signal transducer PI3K. Science (2010) 329(5996):1210-4. doi:10.1126/science.1187996

126. Witherden DA, Watanabe M, Garijo O, Rieder SE, Sarkisyan G, Cronin SJF, et al. The CD100 receptor interacts with its plexin B2 ligand to regulate epidermal $\gamma \delta$ T cell function. Immunity (2012) 37(2):314-25. doi:10.1016/j.immuni. 2012.05.026

127. Meehan TF, Witherden DA, Kim C-H, Sendaydiego K, Ye I, Garijo O, et al. Protection against colitis by CD100-dependent modulation of intraepithelial $\gamma \delta \mathrm{T}$ lymphocyte function. Mucosal Immunol (2014) 7(1):134-42. doi:10.1038/mi. 2013.32

128. Shi W, Kumanogoh A, Watanabe C, Uchida J, Wang X, Yasui T, et al. The class IV semaphorin CD100 plays nonredundant roles in the immune system: 
defective B and T cell activation in CD100-deficient mice. Immunity (2000) 13(5):633-42. doi:10.1016/S1074-7613(00)00063-7

129. Park O, Jeong W-I, Wang L, Wang H, Lian Z-X, Gershwin ME, et al. Diverse roles of invariant natural killer $\mathrm{T}$ cells in liver injury and fibrosis induced by carbon tetrachloride. Hepatology (2009) 49(5):1683-94. doi:10.1002/hep.22813

130. Sagiv A, Biran A, Yon M, Simon J, Lowe SW, Krizhanovsky V. Granule exocytosis mediates immune surveillance of senescent cells. Oncogene (2013) 32(15):1971-7. doi:10.1038/onc.2012.206

131. Devey L, Ferenbach D, Mohr E, Sangster K, Bellamy CO, Hughes J, et al. Tissueresident macrophages protect the liver from ischemia reperfusion injury via a heme oxygenase-1-dependent mechanism. Mol Ther (2009) 17(1):65-72. doi:10.1038/mt.2008.237

132. Girardi M, Lewis J, Glusac E, Filler RB, Geng L, Hayday AC, et al. Resident skin-specific gamma delta $\mathrm{T}$ cells provide local, non-redundant regulation of cutaneous inflammation. J Exp Med (2002) 195(7):855-67. doi:10.1084/jem. 20012000

133. Girardi M, Lewis JM, Filler RB, Hayday AC, Tigelaar RE. Environmentally responsive and reversible regulation of epidermal barrier function by $\gamma \delta \mathrm{T}$ cells. J Invest Dermatol (2006) 126(4):808-14. doi:10.1038/sj.jid.5700120

134. Sharp LL, Jameson JM, Cauvi G, Havran WL. Dendritic epidermal T cells regulate skin homeostasis through local production of insulin-like growth factor 1. Nat Immunol (2005) 6(1):73-9. doi:10.1038/nil152

135. Jameson J, Havran WL. Skin gammadelta T-cell functions in homeostasis and wound healing. Immunol Rev (2007) 215:114-22. doi:10.1111/j.1600-065X. 2006.00483.x

136. Jameson J, Ugarte K, Chen N, Yachi P, Fuchs E, Boismenu R, et al. A role for skin gamma delta $\mathrm{T}$ cells in wound repair. Science (2002) 296(5568):747-9. doi:10.1126/science.1069639

137. Chen Y, Chou K, Fuchs E, Havran WL, Boismenu R. Protection of the intestinal mucosa by intraepithelial gamma delta T cells. Proc Natl Acad Sci U S A (2002) 99(22):14338-43. doi:10.1073/pnas.212290499

138. Senovilla L, Galluzzi L, Zitvogel L, Kroemer G. Immunosurveillance as a regulator of tissue homeostasis. Trends Immunol (2013) 34(10):471-81. doi:10.1016/j.it.2013.06.005

139. Vesely MD, Kershaw MH, Schreiber RD, Smyth MJ. Natural innate and adaptive immunity to cancer. Annu Rev Immunol (2011) 29(1):235-71. doi:10.1146/ annurev-immunol-031210-101324

140. Dunham LJ. Cancer in man at site of prior benign lesion of skin or mucous membrane: a review. Cancer Res (1972) 32(7):1359-74.

141. Walter ND, Rice PL, Redente EF, Kauvar EF, Lemond L, Aly T, et al. Wound healing after trauma may predispose to lung cancer metastasis: review of potential mechanisms. Am J Respir Cell Mol Biol (2011) 44(5):591-6. doi:10.1165/rcmb. 2010-0187RT

142. Ortiz-Urda S. Type VII collagen is required for ras-driven human epidermal tumorigenesis. Science (2005) 307(5716):1773-6. doi:10.1126/science.1106209

143. South AP, O'Toole EA. Understanding the pathogenesis of recessive dystrophic epidermolysis bullosa squamous cell carcinoma. Dermatol Clin (2010) 28(1):171-8. doi:10.1016/j.det.2009.10.023

144. Dvorak HF. Tumors: wounds that do not heal. Similarities between tumor stroma generation and wound healing. N Engl J Med (1986) 315(26):1650-9. doi:10.1056/NEJM198612253152606

145. Coussens LM, Zitvogel L, Palucka AK. Neutralizing tumor-promoting chronic inflammation: a magic bullet? Science (2013) 339(6117):286-91. doi:10.1126/ science. 1232227

146. Balkwill F, Mantovani A. Inflammation and cancer: back to Virchow? Lancet (2001) 357(9255):539-45. doi:10.1016/S0140-6736(00)04046-0

147. Farhadi N, Lambert L, Triulzi C, Openshaw PJ, Guerra N. Natural killer cell NKG2D and granzyme B are critical for allergic pulmonary inflammation. J Allergy Clin Immunol (2014) 133(3):827-35. doi:10.1016/j.jaci.2013.09.048

148. Oh M-H, Oh SY, Yu J, Myers AC, Leonard WJ, Liu YJ, et al. IL-13 induces skin fibrosis in atopic dermatitis by thymic stromal lymphopoietin. J Immunol (2011) 186(12):7232-42. doi:10.4049/jimmunol.1100504

149. Wilson SR, Thé L, Batia LM, Beattie K, Katibah GE, McClain SP, et al. The epithelial cell-derived atopic dermatitis cytokine TSLP activates neurons to induce itch. Cell (2013) 155(2):285-95. doi:10.1016/j.cell.2013.08.057

150. Metz M, Piliponsky AM, Chen CC, Lammel V, Abrink M, Pejler G, et al. Mast cells can enhance resistance to snake and honeybee venoms. Science (2006) 313(5786):526-30. doi:10.1126/science.1128877
151. Schneider LA, Schlenner SM, Feyerabend TB, Wunderlin M, Rodewald H-R. Molecular mechanism of mast cell mediated innate defense against endothelin and snake venom sarafotoxin. J Exp Med (2007) 204(11):2629-39. doi:10.1084/ jem. 20071262

152. Matsuda H, Watanabe N, Kiso Y, Hirota S, Ushio H, Kannan Y, et al. Necessity of IgE antibodies and mast cells for manifestation of resistance against larval Haemaphysalis longicornis ticks in mice. J Immunol (1990) 144(1): 259-62.

153. Pearce EJ, Cheever A, Leonard S, Covalesky M, Fernandez-Botran R, Kohler G, et al. Schistosoma mansoni in IL-4-deficient mice. Int Immunol (1996) 8(4):435-44. doi:10.1093/intimm/8.4.435

154. Gause WC, Wynn TA, Allen JE. Type 2 immunity and wound healing: evolutionary refinement of adaptive immunity by helminths. Nat Rev Immunol (2013) 13(8):607-14. doi:10.1038/nri3476

155. Monticelli LA, Sonnenberg GF, Abt MC, Alenghat T, Ziegler CGK, Doering $\mathrm{TA}$, et al. Innate lymphoid cells promote lung-tissue homeostasis after infection with influenza virus. Nat Immunol (2011) 12(11):1045-54. doi:10.1031/ ni.2131

156. Rosenberg HF, Dyer KD, Foster PS. Eosinophils: changing perspectives in health and disease. Nat Rev Immunol (2013) 13(1):9-22. doi:10.1038/nri3341

157. Okumura S, Sagara H, Fukuda T, Saito H, Okayama Y. FceRI-mediated amphiregulin production by human mast cells increases mucin gene expression in epithelial cells. J Allergy Clin Immunol (2005) 115(2):272-9. doi:10. 1016/j.jaci.2004.12.835

158. Arwert EN, Hoste E, Watt FM. Epithelial stem cells, wound healing and cancer. Nat Rev Cancer (2012) 12(3):170-80. doi:10.1038/nrc3217

159. Conticello C, Pedini F, Zeuner A, Patti M, Zerilli M, Stassi G, et al. IL4 protects tumor cells from anti-CD95 and chemotherapeutic agents via up-regulation of antiapoptotic proteins. J Immunol (2004) 172(9):5467-77. doi:10.4049/jimmunol.172.9.5467

160. Golumbek PT, Lazenby AJ, Levitsky HI, Jaffee LM, Karasuyama H, Baker $\mathrm{M}$, et al. Treatment of established renal cancer by tumor cells engineered to secrete interleukin-4. Science (1991) 254(5032):713-6. doi:10.1126/science. 1948050

161. Hock H, Dorsch M, Kunzendorf U, Qin Z, Diamantstein T, Blankenstein T. Mechanisms of rejection induced by tumor cell-targeted gene transfer of interleukin 2, interleukin 4, interleukin 7, tumor necrosis factor, or interferon gamma. Proc Natl Acad Sci U S A (1993) 90(7):2774-8. doi:10.1073/ pnas.90.7.2774

162. Pericle F, Giovarelli M, Colombo MP, Ferrari G, Musiani P, Modesti A, et al. An efficient Th2-type memory follows CD8+ lymphocyte-driven and eosinophilmediated rejection of a spontaneous mouse mammary adenocarcinoma engineered to release IL-4. J Immunol (1994) 153(12):5659-73.

163. Rodolfo M, Zilocchi C, Accornero P, Cappetti B, Arioli I, Colombo MP. IL-4transduced tumor cell vaccine induces immunoregulatory type 2 CD8 T lymphocytes that cure lung metastases upon adoptive transfer. J Immunol (1999) 163(4):1923-8.

164. Ellyard JI, Simson L, Parish CR. Th2-mediated anti-tumour immunity: friend or foe? Tissue Antigens (2007) 70(1):1-11. doi:10.1111/j.1399-0039.2007. 00869.x

165. Chen S-F, Nieh S, Jao S-W, Wu M-Z, Liu C-L, Chang Y-C, et al. The paracrine effect of cancer-associated fibroblast-induced interleukin-33 regulates the invasiveness of head and neck squamous cell carcinoma. J Pathol (2013) 231(2):180-9. doi:10.1002/path.4226

166. Pedroza-Gonzalez A, Xu K, Wu T-C, Aspord C, Tindle S, Marches F, et al. Thymic stromal lymphopoietin fosters human breast tumor growth by promoting type 2 inflammation. J Exp Med (2011) 208(3):479-90. doi:10.1084/ jem.20102131

167. Hallett MA, Venmar KT, Fingleton B. Cytokine stimulation of epithelial cancer cells: the similar and divergent functions of IL-4 and IL-13. Cancer Res (2012) 72(24):6338-43. doi:10.1158/0008-5472.CAN-12-3544

168. Renard N, Duvert V, Banchereau J, Saeland S. Interleukin-13 inhibits the proliferation of normal and leukemic human B-cell precursors. Blood (1994) 84(7):2253-60.

169. Blais Y, Gingras S, Haagensen DE, Labrie F, Simard J. Interleukin-4 and interleukin-13 inhibit estrogen-induced breast cancer cell proliferation and stimulate GCDFP-15 expression in human breast cancer cells. Mol Cell Endocrinol (1996) 121(1):11-8. doi:10.1016/0303-7207(96)03843-9 
170. Obiri NI, Husain SR, Debinski W, Puri RK. Interleukin 13 inhibits growth of human renal cell carcinoma cells independently of the p140 interleukin 4 receptor chain. Clin Cancer Res (1996) 2(10):1743-9.

171. Fujisawa T, Joshi BH, Puri RK. IL-13 regulates cancer invasion and metastasis through IL-13R $\alpha 2$ via ERK/AP-1 pathway in mouse model of human ovarian cancer. Int J Cancer (2012) 131(2):344-56. doi:10.1002/ijc.26366

172. Simson L, Ellyard JI, Dent LA, Matthaei KI, Rothenberg ME, Foster PS, et al. Regulation of carcinogenesis by IL-5 and CCL11: a potential role for eosinophils in tumor immune surveillance. J Immunol (2007) 178(7):4222-9. doi:10.4049/jimmunol.178.7.4222

173. Dalton DK, Noelle RJ. The roles of mast cells in anticancer immunity. Cancer Immunol Immunother (2012) 61(9):1511-20. doi:10.1007/s00262-0121246-0

174. Vernersson M, Aveskogh M, Hellman L. Cloning of IgE from the echidna (Tachyglossus aculeatus) and a comparative analysis of epsilon chains from all three extant mammalian lineages. Dev Comp Immunol (2004) 28(1):61-75. doi:10.1016/S0145-305X(03)00084-3

175. Jensen-Jarolim E, Achatz G, Turner MC, Karagiannis S, Legrand F, Capron $\mathrm{M}$, et al. AllergoOncology: the role of IgE-mediated allergy in cancer. Allergy (2008) 63(10):1255-66. doi:10.1111/j.1398-9995.2008.01768.x

176. Reali E, Greiner JW, Corti A, Gould HJ, Bottazzoli F, Paganelli G, et al. IgEs targeted on tumor cells: therapeutic activity and potential in the design of tumor vaccines. Cancer Res (2001) 61(14):5517-22.

177. Karagiannis P, Gilbert AE, Josephs DH, Ali N, Dodev T, Saul L, et al. IgG4 subclass antibodies impair antitumor immunity in melanoma. J Clin Invest (2013) 123(4):1457-74. doi:10.1172/JCI65579

178. Olver S, Groves P, Buttigieg K, Morris ES, Janas ML, Kelso A, et al. Tumorderived interleukin-4 reduces tumor clearance and deviates the cytokine and granzyme profile of tumor-induced CD8+ T cells. Cancer Res (2006) 66(1):571-80. doi:10.1158/0008-5472.CAN-05-1362

179. Lebel-Binay S, Laguerre B, Quintin-Colonna F, Conjeaud H, Magazin M, Miloux B, et al. Experimental gene therapy of cancer using tumor cells engineered to secrete interleukin-13. Eur J Immunol (1995) 25(8):2340-8. doi:10.1002/eji.1830250833

180. Skinnider BF, Elia AJ, Gascoyne RD, Patterson B, Trumper L, Kapp U, et al. Signal transducer and activator of transcription 6 is frequently activated in Hodgkin and Reed-Sternberg cells of Hodgkin lymphoma. Blood (2002) 99(2):618-26. doi:10.1182/blood.V99.2.618

181. Jovanovic I, Radosavljevic G, Mitrovic M, Juranic VL, McKenzie ANJ, Arsenijevic N, et al. ST2 deletion enhances innate and acquired immunity to murine mammary carcinoma. Eur J Immunol (2011) 41(7):1902-12. doi:10.1002/eji. 201141417

182. Jovanovic IP, Pejnovic NN, Radosavljevic GD, Pantic JM, Milovanovic $\mathrm{MZ}$, Arsenijevic NN, et al. Interleukin-33/ST2 axis promotes breast cancer growth and metastases by facilitating intratumoral accumulation of immunosuppressive and innate lymphoid cells. Int J Cancer (2013) 134(7):1669-82. doi:10.1002/ijc.28481
183. Villarreal D, Wise MC, Walters JN, Reuschel E, Choi MJ, Obeng-Adjei N, et al. Alarmin IL-33 acts as an immunoadjuvant to enhance antigen-specific tumor immunity. Cancer Res (2014) 74(6):1-12. doi:10.1158/0008-5472.CAN13-2729

184. Nigro EA, Brini AT, Soprana E, Ambrosi A, Dombrowicz D, Siccardi AG, et al. Antitumor IgE adjuvanticity: key role of Fc RI. J Immunol (2009) 183(7):4530-6. doi:10.4049/jimmunol.0900842

185. McWhorter WP. Allergy and risk of cancer. A prospective study using NHANESI follow up data. Cancer (1988) 62(2):451-5. doi:10.1002/10970142(19880715)62:2<451::AID-CNCR2820620234>3.0.CO;2-D

186. Josephs DH, Spicer JF, Corrigan CJ, Gould HJ, Karagiannis SN. Epidemiological associations of allergy, IgE and cancer. Clin Exp Allergy (2013) 43(10):1110-23. doi:10.1111/cea.12178

187. Sherman PW, Holland E, Sherman JS. Allergies: their role in cancer prevention. Q Rev Biol (2008) 83(4):339-62. doi:10.1086/592850

188. Rittmeyer D, Lorentz A. Relationship between allergy and cancer: an overview. Int Arch Allergy Immunol (2012) 159(3):216-25. doi:10.1159/000338994

189. Engkilde K, Thyssen JP, Menné T, Johansen JD. Association between cancer and contact allergy: a linkage study. BMJ Open (2011) 1(1):e000084. doi:10.1136/bmjopen-2011-000084

190. Van Hemelrijck M, Garmo H, Binda E, Hayday A, Karagiannis SN, Hammar N, et al. Immunoglobulin E and cancer: a meta-analysis and a large Swedish cohor study. Cancer Causes Control (2010) 21(10):1657-67. doi:10.1007/s10552-0109594-6

191. Lindelof B, Granath F, Tengvall-Linder M, Ekbom A. Allergy and cancer. Allergy (2005) 60(9):1116-20. doi:10.1111/j.1398-9995.2005.00808.x

Conflict of Interest Statement: The Guest Associate Editor Fang-Ping Huang declares that, despite being affiliated to the same institution as authors Tim Dalessandri and Jessica Strid, the review process was handled objectively and no conflict of interest exists. The authors declare that the research was conducted in the absence of any commercial or financial relationships that could be construed as a potential conflict of interest.

Received: 10 March 2014; accepted: 08 July 2014; published online: 22 July 2014. Citation: Dalessandri T and Strid J (2014) Beneficial autoimmunity at body surfaces immune surveillance and rapid type 2 immunity regulate tissue homeostasis and cancer. Front. Immunol. 5:347. doi: 10.3389/fimmu.2014.00347

This article was submitted to Tumor Immunity, a section of the journal Frontiers in Immunology.

Copyright (c) 2014 Dalessandri and Strid. This is an open-access article distributed under the terms of the Creative Commons Attribution License (CC BY). The use, distribution or reproduction in other forums is permitted, provided the original author(s) or licensor are credited and that the original publication in this journal is cited, in accordance with accepted academic practice. No use, distribution or reproduction is permitted which does not comply with these terms. 